\title{
Spatially explicit assessment of roundwood and logging residues availability and costs for the EU 28
}

\section{Fulvio Di Fulvio, Nicklas Forsell, Ola Lindroos, Anu Korosuo \& Mykola Gusti}

To cite this article: Fulvio Di Fulvio, Nicklas Forsell, Ola Lindroos, Anu Korosuo \& Mykola Gusti (2016): Spatially explicit assessment of roundwood and logging residues availability and costs for the EU 28, Scandinavian Journal of Forest Research, DOI: 10.1080/02827581.2016.1221128

To link to this article: http://dx.doi.org/10.1080/02827581.2016.1221128

Accepted author version posted online: 05

Aug 2016.

Published online: 05 Aug 2016.

Submit your article to this journal $₫$

ai

View related articles $\sqsubset$

View Crossmark data $₫$ 
Publisher: Taylor \& Francis \& Informa UK Limited, trading as Taylor \& Francis Group

Journal: Scandinavian Journal of Forest Research

DOI: $10.1080 / 02827581.2016 .1221128$

\title{
Spatially explicit assessment of roundwood and logging residues availability and costs for the EU 28
}

Fulvio Di Fulvio*ab, Nicklas Forsell $^{\mathrm{a}}$, Ola Lindroos ${ }^{\mathrm{b}}$, Anu Korosuo ${ }^{\mathrm{a}}$, Mykola Gustia,

\begin{abstract}
Competition for woody biomass between material and energy uses is expected to further increase in the future, due to the limited availability of forest resources and increasing demand of wood for material and bioenergy. Currently, methodological approaches for modeling wood production and delivery costs from forest to industrial gates are missing. This study combines forest engineering, geographically explicit information, environmental constraints, and economics in a bottom up approach to assess cost-supply curves. The estimates are based on a multitude of wood supply systems that were assigned according to geographically explicit forestry characteristics. For each harvesting and transportation system, efficiencies were modeled according to harvesting sites and main delivery hubs. The cost supply curves for roundwood and logging residues as estimates for current time and for the future (2030) show that there are large regional differences in the potential to increase extraction in the EU28. In most EU Member States, the costs of logging residues extraction increase exponentially already for low levels of mobilization, while extraction of roundwood can be increased to a larger extent within reasonable costs (30-40 \$/ $\mathrm{m}^{3}$ ). The large differences between countries in their harvest potential highlight the importance of spatially explicit analyses.
\end{abstract}

Keywords: spatial availability, cost supply curves, woody biomass, supply systems

*Corresponding Author

Ecosystems Services and Management Program (ESM)

International Institute for Applied Systems Analysis (IIASA)

Schlossplatz 1, A-2361 Laxenburg, Austria Phone: +43 2236807469

difulvi@iiasa.ac.at forsell@iiasa.ac.at korosuo@iiasa.ac.at gusti@iiasa.ac.at

b Department of Forest Biomaterials and Technology

Swedish University of Agricultural Sciences 
Skogsmarksgränd 17, 90183 Umeå, Sweden

fulvio.di.fulvio@slu.se Ola.Lindroos@slu.se

c Lviv Polytechnic National University,

12 Bandery Str., 79013 Lviv, Ukraine

\section{Introduction}

The future mobilization of woody biomass for material and energy use in the European Union is expected to increase significantly, due to growing demand for bioenergy and increasing production of semi-finished wood products (EFSOS II 2011, Mantau et al. 2010). The realistic potential of woody biomass from the European forests was estimated to be 747 million $\mathrm{m}^{3}$ per year in 2010, and it is expected to remain almost constant until 2030 (Mantau etal. 2010). Mantau et al. (2010) expected the demand to increase from ca. 800 million $\mathrm{m}^{3}$ to ca. 1300 million $\mathrm{m}^{3}$ (years 2010 to 2030), by far exceeding the amount of biomass available from the forest management. The increase in harvest of wood from forests was suggested to be especially driven by demand for wood for energy, while the market share of material use demand was expected to drop from $55.5 \%$ to $43.5 \%$. Similar development was projected also in the European Forest Sector Outlook Study (EFSOS II, 2011), where the reference scenario expected wood demand for energy alone to increase from 434 million $\mathrm{m}^{3}$ roundwood equivalent in 2010 to 585 million $\mathrm{m}^{3}$ in 2030 . Therefore, additional wood mobilization or large increases in import of biomass are needed to secure adequate resources.

A number of studies have assessed the future potential woody biomass in the EU for material (Mantau et al. 2010, Verkerk et al. 2011) and for energy uses (Asikainen et al. 2008, Lauri et al. 2014, Daioglou et al. 2015). These studies considered spatially explicit biophysical features and land uses change for estimating the theoretical potentials and applied a series of ecological, technical and social constraints for assessing realistic potentials. However, there is a fundamental difference between available resources and the amount which can be delivered to the end user at a cost inferior to the market price - that is, resources that are economically viable.

The available amount of biomass in a certain geographical area can be associated with its delivery costs by means of cost supply curves, which show the increase of costs when enlarging the supply (Binkley and Dykstra 1987). These curves reflect the resource accessibility mechanisms, where the resources available at the lowest cost are firstly mobilized and afterwards when the demand increases, remote resources are mobilized at higher costs. Cost supply curves are useful for investigating relations between prices at the industry gate and amount mobilized, and also for benchmarking the supply of different resources. These curves can be considered to hold in the short run, while in a longer term, variations in the forest growth, infrastructures, location of industrial facilities, and afforestation/deforestation events may change the slope of the costsupply curves.

Several studies have shown potentials and costs of forest resources by applying the cost supply curves approach in specific regions or entire countries (Galik et al. 2009, Hock et al. 2012, Yemshanov 2014, Lundmark et al. 2015) and in some cases also in regions such as the EU and on the global level (de Wit \& Faaij 2010, Sikkema et al. 2014). However, as pointed out in assessments of future potentials for woody biomass in the EU (Verkerk et al. 2011, Lauri et al. 2014), there is still need for more detailed analyses of the cost-supply relationship, especially 
such that takes into account the spatial location of end-use facilities with detailed information of transportation networks, capitals, fuels and labor costs (Nordfjell et al. 2004, Siry et al. 2006). In this study we present a new bottom-up approach for assessing and comparing potentials and costs for roundwood and logging residues for the EU28 under different biomass mobilization alternatives and economic development options. The results are shown for current time (2015) and for year 2030. This is to our knowledge the first study that combines detailed spatial information on forest characteristics, location of facilities, and road network to produce detailed costsupply curves for each of the 28 EU Member States.

\section{Material and Methods}

The methodological approach consisted of the following parts:

- Computation of woody biomass potentials by use of the Global Forest Model (G4M)

- Modeling of forest operations and road transportation efficiencies

- Modeling of transportation distances from forests to industries in a network analysis

- Adaptation of costs to the country borders

- Aggregation of results in cost supply curves for each of the European Regions (Table 1)

Table 1. >>>

\section{Available biomass potential}

The assessment of available woody biomass potential for current time (2015) and 2030 was based on a spatially explicit information acquired from the global forest model (G4M).

G4M is a computer model simulating land use change and forest management decisions as well as corresponding dynamics of land cover, forest biomass, harvested wood and $\mathrm{CO}_{2}$ emissions on $0.5 \times 0.5$ degree grid (Kindermann et al. 2008, Gusti, 2010, Gusti \& Kindermann, 2011). The model uses empirical forest growth functions for major tree species in each grid cell (Kindermann et al., 2013). Forest management in G4M is aimed at sustainable harvest of exogenous wood demand on country scale.

For each cell, the characteristics of forests are described through a full range of features covering important aspects such as: country, dominant tree species (Picea sp., Abies sp., Pinus sp., Betula sp., Fagus sp., Quercus sp., and Larix sp.), age structure, mean annual increment, rotation time, treatment (final felling, thinning), tree parameters ( $\mathrm{dbh}=$ diameter at breast height, height), harvested woody biomass (solid $\mathrm{m}^{3} / \mathrm{ha} /$ year), harvestable surface (hectare/year), the model mimics an even-aged forest management ${ }^{1}$.

\footnotetext{
${ }^{1}$ Harvesting of forest areas which are strictly protected according to WDPA (2004) was excluded and no conversion or use of protected forest was allowed. Forests that are not protected are considered as potential production forest. The G4M model allocates harvests to this area so that the demand for wood for material and energy purposes will be satisfied. Forests that are used in a certain period to meet the wood demand (so-called used forests) are modelled to be managed for woody biomass production. This implies
} 
For each cell, G4M generates the harvestable volume of woody biomass divided between two categories:

- Roundwood: stemwood with dimensional characteristics suitable for production of sawnlogs or pulplogs, with top diameters fixed according to specific dimensional requirements in each country.

- Logging residues: harvesting losses (i.e. rotten wood, wood dimensionally unsuitable for roundwood logs), tree branches, and tree tops. Tree branches and tops are calculated with specific biomass expansion factors (Teobaldelli et al. 2009) applied to the stemwood volume.

The forest attributes obtained from G4M were merged with a database of biophysical variables (Skalsky et al. 2008), containing data on soil, topography, climate, land cover with resolution from 5 to 30 arc minutes.

Homogeneous response units were delineated and clustered as five altitude classes, seven slope classes and five soil classes. The clustered units are intersected with a $0.5^{\circ}$ grid and country borders in order to delineate homogenous Simulation Units (SimU).

The current and future harvested volumes (from used forests) in G4M are defined by assuming the fulfillment of the forest biomass demand predicted in the economic model GLOBIOM (Global Biosphere Management Model) (Havlík et al. 2011). Hence, the wood demand from GLOBIOM represents the "maximum potential" harvestable in each alternative considered in our analyses ${ }^{2}$.

a rotation time, thinning events and final harvest. Unused forest do currently not contribute to wood supply (due to economic reasons) and the model allows for conversion from used forests to unused, and unused to used forests. The historical geographical location of harvest within each EU Country has been initialized using a map of wood production from Verkerk et al. (2015), which was applied for sorting the economical harvest suitability of cell in the G4M.

${ }^{2}$ The GLOBIOM is a global partial equilibrium model of the forest and agricultural sectors, where economic optimization is based on the spatial equilibrium modeling approach (Havlík et al. 2011). The demand is based on the interaction of four different drivers: population growth, income per capita growth, bioenergy growth, response to prices. Demand increases linearly with population in each of the 57 GLOBIOM regions (including the $28 \mathrm{EU}$ countries). GDP per capita changes determine demand variation depending on income elasticity values. For the agricultural sector, the income elasticities area calibrated to mimic anticipated FAO projections of diets (Alexandratos and Bruinsma 2012). Income elasticities for the forest sector are taken from Buongiorno et al. (2003). The response of non-energy related uses to commodity prices is endogenously computed in GLOBIOM. Bioenergy demand projections are implemented based on PRIMES projections for forest biomass (EU 2013). Price elasticities for the agricultural commodities are taken from a global database from USDA (Muhammad, et al. 2011) and for the forest sector from Buongiorno et al. (2003). Hence, demand for non-energy (material) wood use are competing for the wood resource with energy uses and are projected endogenously by GLOBIOM. An increase in biomass production prescribed by the output of the PRIMES biomass model is entirely reproduced in GLOBIOM. 
The residues were considered to be technically harvestable in early thinnings and in final fellings. Early thinnings were simulated for forest stands with average stem volume $<150-250$ $\mathrm{dm}^{3}$, with the threshold adjusted according to country.

Ecological restrictions were applied on forest soils sensible to erosion and loss of fertility. For soil erosion, residue extraction in forest areas that have slopes with an inclination $>50 \%$ was not allowed for broadleaved forests and limited to $33 \%$ of conifer sites. On slopes with inclination between $>30$ and $\leq 50 \%$, the extraction was limited to $33 \%$ of broadleaved and $66 \%$ of conifer stands. Forest soils that have low levels of soil carbon content are sensible to losses of site fertility (Repo et al. 2014). For this reason, removal of logging residues was totally excluded from areas where the level of carbon in the topsoil was below $0.6 \%$, determined in EC (2006). Poorly developed soils can also be negatively affected by the extraction of residues, thus soils with depth less than $30 \mathrm{~cm}$ (EC 2006) were also excluded.

Technical losses were modeled according to site specific harvesting and extraction systems. In case of highly mechanized systems (harvester/forwarder based), the losses were assumed to $30 \%$ of total available amount (Nurmi 2007; Wihersaari 2005). For systems based on motormanual felling and processing, losses were assumed to 40\% (Asikainen at al.2008).

\section{Modeling of supply costs}

The cost of supply of woody biomass from each SimU (in $\$$ solid $\mathrm{m}^{3}$ ) to the industry gate included the cost for logging operations and costs for road transportation to the gate. In the case of roundwood from final felling, also the cost for forest regeneration was included. The efficiency of each operation was modeled according to the characteristics of each SimU, and afterwards combined with the unitary costs for operating capitals, labor and fuels adapted to the economic conditions in each of the countries in the EU.

\section{$\underline{\text { Regeneration costs }}$}

Due to the lack of information on the spatial distribution of areas regenerated by human activities within country border, each SimU in final felling was divided according to the regeneration shares in its EU Region (FE 2011): one part regenerated by planting and one naturally regenerated.

The time consumption for regeneration activities was set to 26.8 hours/ha, herein planting was set to17 working hours/ha according to Granhus \& Fjeld (2008), the pre-commercial thinning time consumption to 6.2 hours/ha according to Ligne' et al. (2005), the rest of the time was assumed to be spent in complementary work (eg. soil preparation).

The hourly cost for regeneration was assessed in Sweden according to forest accounting statistics as 43 \$/hour (Brunberg 2014). The adaptation of this cost component to the country borders followed the same adaptation used for the "labor costs" for forest operations (see paragraph "country specific adaptation of unitary costs"), due to the fact that the man-power is the largest component in the semi-mechanized regeneration methods. The cost per hectare for regeneration activities was allocated on the volume of roundwood harvested in final felling from each SimU.

\section{$\underline{\text { Harvesting and primary transportation systems }}$}

The forest harvesting systems applied in the EU can be divided into low mechanized and highly mechanized systems, based on the man-power required (Table 2). In the low mechanized (Sys- 
tem 3-10 in Table 2), tree felling is carried out motor-manually by means of chainsaws, while in the mechanized ones (System 1-2 in Table 2), harvesters are typically used. Another division of systems can be made on the basis of locations where trees are processed into logs. In the cut-tolength (CTL) systems (System1-6), the processing takes place at the forest site (at the stump), while in the whole tree system (WT), trees are processed at the roadside/landings (System 7-10). The extraction of trees/logs can be made with specialized machinery: forwarders, skidders, cable yarders, or by means of farm tractors equipped with forest trailers. In the case of extracting whole trees (WT), roadside processing of trees into assortments needs to be included in the supply chain. This operation can be made with processors mounted on excavators or motormanually using chainsaws.

The selection of harvesting systems to be assigned to each SimU was based on the restrictions listed in Table 3. The size of trees was used as limiting factor for felling with harvesters, the slope as a limiting factor for highly mechanized felling and extraction and the soil bearing capacity as a limiting factor for extraction with heavy machinery (forwarders).

Typically, roundwood harvesting systems in the EU are based on CTL, and WT systems are applied in case of integrating roundwood and residues on steep terrains (i.e. slope above $30 \%$ ). Thus, in the modeling of forest operations, the CTL systems were assumed as reference for calculation of costs in the case of exclusive removal of roundwood, while WT systems were applied to units where roundwood was integrated with residues on slopes above $30 \%$.

In the case of collecting residues in CTL systems, the cost of piling residues during felling is included, and also the time consumption for extraction of residues to the roadside. In case of WT systems, the cost of piling residues at roadside with a processor/chainsaw is included as a cost. In all cases (both CTL and WT), chipping at the roadside by means of truck-mounted chippers is included as a cost in the supply chain of residues (Table 2).

To account for areas where unfrozen peatlands prevent the use of heavy machinery (forwarders), a map of soil freezing areas (freezing at least for one month at $20 \mathrm{~cm}$ depth) was created for the EU, based on WorldClim (2015) and Beltrami (2001). The soil freezing map was merged with the peatland dominated SimUs for selecting areas where forwarders where assumed not being able to be used.

A decisional support framework was used for selecting of harvesting systems applied in each SimU (Figure 1). Firstly, it considers whether logging residues are extracted, for selecting between CTL and WT systems. Secondly, technical restrictions for each machinery (Table 3) are considered. Skidders are applied only in a SimU unsuitable for forwarders/farm tractors and cable yarders are assigned to units unsuitable for the rest of machineries. Finally, the selection between high mechanized forest systems (harvester, forwarder, and processor) and low mechanized (chainsaw, farm tractor) is obtained by applying the system with the lowest cost per unit of product (Figure 1).

Figure $1>>>$

Table $2>>>$ 
Table 3 >>>

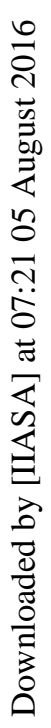

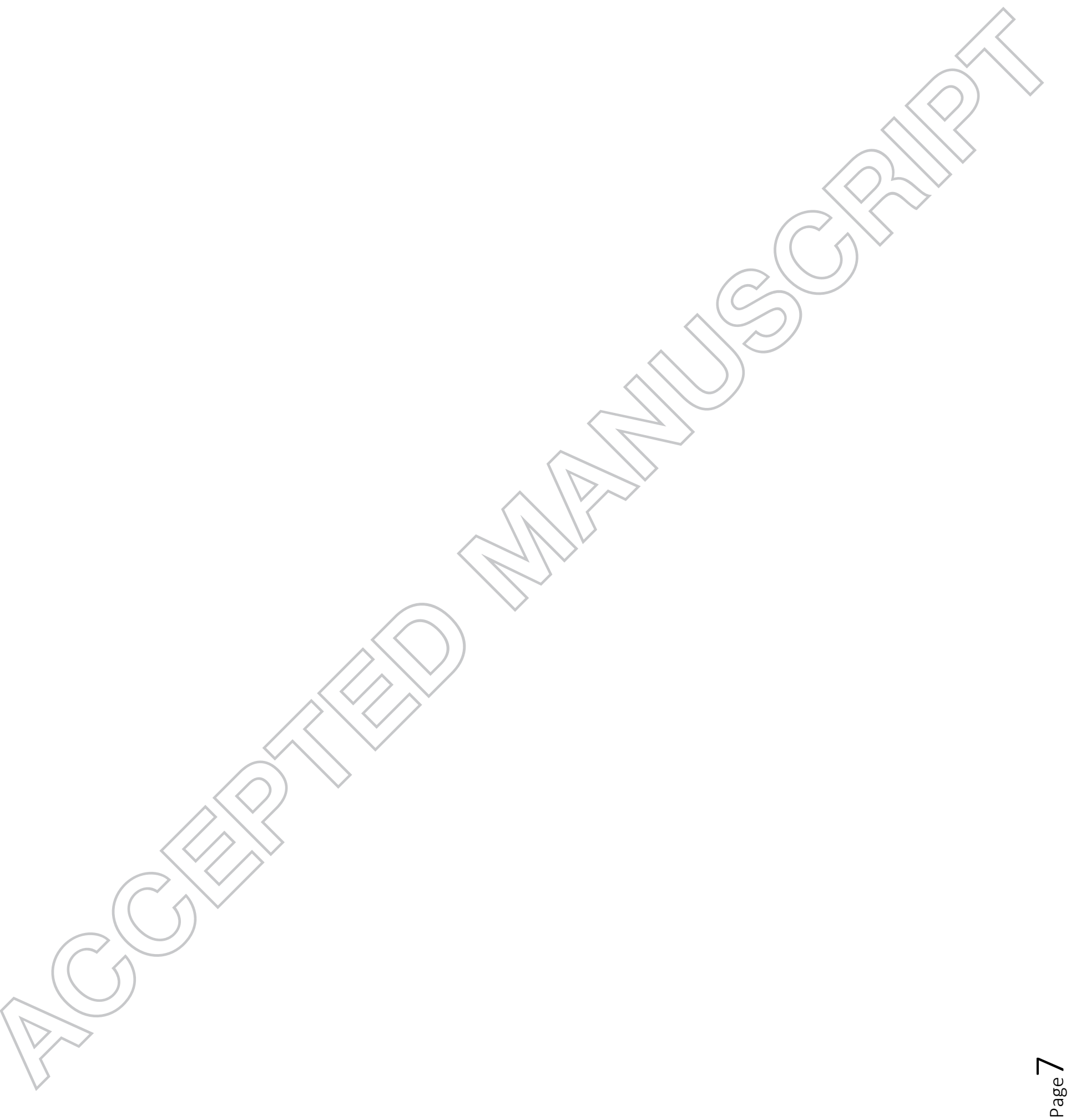


Two truck and trailers systems were included in the supply model. One is based on typical trucks and a trailer used for transportation of logs (pulp logs and sawlogs) for transportation of roundwood. The other one considered was a container truck for transportation of chipped logging residues.

\section{Modeling of harvesting and transportation efficiencies}

A series of time consumption models for forest machinery and road transportation were collected from the literature. Each model provides the time consumption per harvested unit (solid $\mathrm{m}^{3}$ ), given a set of spatial explicit variables for each SimU. The biophysical variables included were terrain and forest features. The variables included in each time consumption model are used for adaptation of time consumption to the SimU according to Annex 1.

Technical and economic utilization factors, based on follow up studies, were collected for each machinery/equipment and applied for conversion of effective time consumption (effective minutes $/ \mathrm{m}^{3}$ ) (Annex 1) into gross time consumption (scheduled machine hours $/ \mathrm{m}^{3}$ ) and for assessing the economic life of different machinery/equipment (Annex 2).

Both work efficiencies and technical and economic utilization factors were assumed to be little influenced by the demographic borders, assuming an average operator and average magnitude for the forest companies, irrespective of country border.

\section{Country border adaptation of time-unit costs}

The time-unit cost in forest operations according to Ackerman et al. (2014) can be divided in three main components: fixed, operational, and labor costs.

The fixed costs are composed of capital costs, represented by depreciation and interests on the invested capitals. Other fixed costs are annual costs for insurances, taxes, registrations, and garaging of equipment.

Operational costs include fuels, lubricants, maintenance and repair, running gears, and other consumables. These costs are solely incurred when the machine engine is running, therefore can be calculated as a costs per SMH (cf. Ackerman et al. 2014).

The fuel cost can be calculated by multiplying the fuel price by the fuel consumption per hour. The lubricant cost is commonly estimated as percentage on fuel costs.

The cost formaintenance and repairs is based on the annual cost records incurred in workshops, or in case it is not directly available, it is estimated as a percentage on purchase price.

The labor cost includes wages directly paid to operators for their work and indirect costs, such as social charges and other benefits (daily allowances, insurance, transport, etc.). Wages are usually paid per scheduled work hours (SMH).

On the top of the direct costs, also overheads are incurred when owning and operating production assets, representing general administration costs for a company. These costs are difficult to allocate to specific production items, therefore an average value can be assumed.

Time-unit costs for machinery and labor are country specific, thus needing an adaptation across borders. For that scope, hourly costs (per SMH) for each machinery system were collected from databases in Reference countries and divided between the most relevant cost components according to Annex 3. The costs are collected in local currencies (LCU). The fixed and operation- 
al costs are converted into international U.S. dollars (\$) using official exchange rates ${ }^{3}$, and labor costs are converted to comparable units using Purchasing Power Parity conversion factors (PPPs) ${ }^{4}$. A global benchmarking exercise was initiated in September 2014 with a group of experts from 15 countries, as listed in Annex 4. A detailed description of hourly cost for a machinery felling trees was collected from the experts with a standardized procedure according to Ackerman et al. (2014). The exercise explored the needing for adaptation to the country borders for each of the time-unit cost components and parameters.

The results from the benchmarking exercise evidenced the need for adaptation to the country border of the following time-unit cost components: Purchase price, Interest rate, Insurance, Fuel price, Maintenance and repair cost, Labor cost.

${ }^{3}$ The official exchange rates were collected from the World Bank \& International Monetary Fund (IMF) (http://data.worldbank.org; www.imf.org). The exchange rates are affected by short time fluctuations. As we thrive to reflect the long term exchange situation, we selected a 5 years average exchange rate (20092013) (see Annex 5).

4 The PPP conversion factor expresses the number of units of a country's currency required to buy the same amounts of goods and services in the domestic market as U.S. dollar would buy in the United States. The PPP conversion factor was obtained from The World Bank International Comparison Program database (http://data.worldbank.org ), the average of last 5 available years was used (2009-2013), the PPP conversion factor is available for 199 countries (see Annex 5). 
Forest production assets are mostly traded on international markets. Therefore, the country border adaptation for purchase prices for machinery/equipment $(P C)$ was found to be dependent on the level of protection on local markets represented by trade tariffs ${ }^{5}(T f)$ and the profitability of forest markets expressed by the value added per employee from roundwood production (VAE) ${ }^{6}$ (Annex 5).

The following regression is proposed in the adaptation of purchase price of machinery to a Country " $\mathrm{j}$ " border:

Purchase price $(\$)_{j}=R p c \times\left(\frac{(990 \mathrm{Bg}+909 \times \mathrm{VAE})}{1-T_{f} / 100}\right)$

The adaptation was based on the purchase price of an harvester, for other machineries the factor Rpc (ratio to harvester purchase price) is needed for correcting their price level compared to an harvester (see Annex 3).

Interest rates were found to be correlated to the risk for investment in the different countries, represented by the international country risk index $\left(I C R G^{7}\right)$, and the following country border adaptation is proposed:

Interest rate $(\%) j=81.8707-17.4439 \times \ln ($ ICRG $) \quad$ (Eq. 4)

Insurances were found to be dependent on purchase prices, therefore their adaptation to the country borders was indirectly obtained by the adaptation of purchase prices.

The adaptation of fuel prices from the reference country "Ref" to the Country " $j$ ” border is obtained by use of the "net official fuel sale prices" (Annex 5) as:

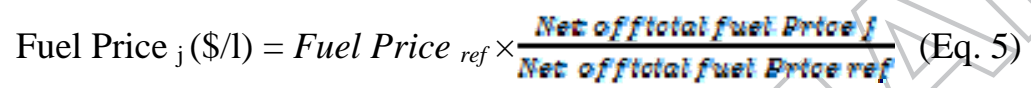

Maintenance and repair costs are commonly assessed as percentage on the purchase prices, therefore, as for the insurances, their adaptation is obtained by the adaptation of purchase prices to country borders.

In forestry, labor force is locally available, and its cost is expected to be connected to the cost of living in the different countries. The labor cost is formed of wages and social charges, and these two components

${ }^{5}$ The international trade tariffs for manufactured products are available from The World Bank (http://data.worldbank.org/ ). The average value for period 2009-2013 was used: the data was available for 172 countries and measured as a percentage on the price of traded commodity. (Annex 5).

${ }^{6}$ Gross value added per capita from roundwood production (VAE) (\$ per capita): the value added per capita was calculated by dividing the Gross Valued Added from roundwood production (\$) by the number of employees in roundwood production. Both data were retrieved from FAO (FAO 2014) and were available for the year 2011 for 175 countries. (Annex 5).

7 The International Country Risk Guide (ICRG) (https://www.prsgroup.com) is a 5-year composite index forecast that expresses the overall concern for investing in a specific country, providing a combined rating for political, financial and economic risk factors for each country. This forecast was available for 139 countries. The index assumes values between 0 and 100, where higher values represent lower risk. (Annex 5).

${ }^{8}$ A global collection of gasoline and diesel prices was retrieved from GIZ (2013). The most recent update for GIZ was released for 165 countries (year 2012). Value added taxes (VAT) are commonly excluded from the computation of costs incurred by forest companies, therefore VATs were collected from The World Bank Group database (http://www.doingbusiness.org) and subtracted from the diesel price from GIZ, obtaining a net official fuel price (Annex 5). 
are treated separately. Wages were correlated to the PPP ratios ${ }^{9}$ (Annex 5) and adapted by using the relation between PPP ratios in different countries as:

Wage $_{\mathrm{j}}(\$ / \mathrm{SMH})=$ Wage ref $\times \frac{\text { PEP ratio } f}{\text { DPE ratio ref }}$ (Eq. 6)

Country specific social charges are added to the wages according to the country border labor cost/wage ratio $^{10}$ (Annex 5).

The total cost for harvesting system in a generic country (j) is determined according to Eq. 7.

Total Harvesting Cost $=\sum_{1}^{t} \frac{T \sigma_{0} \times C_{i}}{60 \times U_{i}}+$ Oh; $(i=$ operation; $j=$ country $)\left(\mathrm{USD} / \mathrm{m}^{3}\right)($ Eq. 7$)$

$t c_{i}=$ time consumption in the operation (i), given by the Annex 1.

$\mathrm{Cj}=$ country border adapted hourly cost for operation (i), given by the cost parameters in Annex 3 and the specific adaptations by Eq. 3-6.

$U_{i}=$ Utilization rate of machinery used in operation (i), given in Annex 2.

$\mathrm{Oh}=$ overhead costs; overheads are incurred when owning and operating production assets, they represent general administration costs for forest companies. In the benchmarking exercise, their level varied between $5-15 \%$ of direct costs, depending on the size of forest enterprises, therefore a $7 \%$ on operational costs is assumed for an average condition.

In Systems including cable yarding (CYL, CYW), the total costs is also increased by $2.38 \$ / \mathrm{m}^{3}$ for installation of cable lines and this cost is adapted to the country border according to labor costs (i.e. Austria as Reference Country).

\section{Modeling of transportation distances}

The open street map (OSM 2015) was used as information layer for road network analyses. The industrial facilities in each country were assumed to be located in the largest cities according to population sizes, as a proxy for real locations of current industries. The number of cities chosen for each country was assigned to match the number of industrial facilities in that country. First, we took the average between the number of pulpmills (Annex 6-7) and woody biomass power plants ( $>0.2 \mathrm{MW}$ ). Then we chose a corresponding number of cities, in the order of their population count and starting from the largest. Sawmills were excluded from the analysis, due to the unpredictability of their business life. A database of current industries (RISI) was used as reference for current number of pulp and paper mills, and the Platts (2013) for the woody biomass power plants (including co-firing industries).

${ }^{9}$ The PPP level ratio, also referred to as the national price level (price level ratio of PPP conversion factor to market exchange rate), makes it possible to compare the cost of the bundle of goods that make up the gross domestic product (GDP) across countries. It tells how many dollars are needed to buy a dollar's worth of goods in the country as compared to the United States. The price level ratio of PPP was obtained from the World Bank International Comparison Program database (http://data.worldbank.org ), the average of last 5 available years (2009-2013) was available for 182 countries (Annex 5).

${ }^{10}$ Social charges on wages were obtained from The World Bank Group database (http://www.doingbusiness.org ), the information was available for 174 countries and applied to the country borders (Annex 5). 


\section{Modeling of transportation costs}

A methodology similar to the one used for forest machinery was applied for adaptation of transportation costs to and across the country borders (see Annex 8). 


\section{$\underline{\text { Sensitivity analyses }}$}

The sensitivity analysis focuses on assessing the impacts of changes on transportation costs, economic conditions, and woody biomass demand.

In the Standardized Transport alternative, the effect on supply curves of transportation distances to industries was evaluated by considering a fixed transportation distance of $50 \mathrm{~km}$ for all harvested units (SimUs).

The cost-supply curves for2030 were calculated for two alternatives named Economic Growth and Forestry Intensification, in order to gain insights on how changes in crucial parameters influence the shape and form of the cost-supply curves.

In the Economic Growth alternative, the price of diesel and GDP per capita in each country were assumed to develop according to the forecast for 2030 made according to the "EU Reference Scenario" (EU 2013). The growth of wages in the reference countries was estimated by applying a deflator of 0.85 to the growth of GDP per capita, based on the long term relation found by Chien \& Arias (2015). The PPP ratios in this case were obtained by comparing the differences in expected growth of GDP in the different countries. The expected variation of GDP per capita, PPP ratios and diesel prices applied in this new scenario are listed in Annex 11. The maximum potential of harvestable woody biomass (i.e. used forests) is assumed the same as in the Reference.

In the Forestry Intensification alternative, the used forest area expands due to higher share of future demand for bioenergy allocated to forests. This is based on assumption of scarce development of dedicated bioenergy crops compared to the Reference (miscanthus, switchgrass and short rotation coppice reach 3.1 $\mathrm{M}$ ha compared to $7.1 \mathrm{M}$ ha). In the Forestry Intensification, the growth of GDP and fuel prices are expected to be the same as in the Economic Growth and the bioenergy demand to be the same as in the "EU Reference Scenario" (EU 2013).

\section{Results}

EU Region level

The results are clustered according to geographical regions within the EU (Figure 2-3-4). The total harvested volume of roundwood in the "Reference scenario" is estimated to be $584 \mathrm{Mm}^{3}$. Of this total potential 39\% is expected from Central-West countries, 34\% from the North of EU, 16\% from Central-East, 8\% from South-West and 3\% from South-East.

The current amounts mobilized correspond generally to a cost level of ca. 26-34 $\$ / \mathrm{m}^{3}$ (Figure 2). In the whole EU, it would be possible to mobilize $56 \%\left(329 \mathrm{Mm}^{3}\right)$ of the total projected harvest at a cost below $30 \$ / \mathrm{m}^{3}$. When increasing the cost to $40 \$ / \mathrm{m}^{3}$, the mobilized roundwood amount reached $482 \mathrm{Mm}^{3}$ (82\% of potential). North and Central-West EU has capacity to increased their amount respectively of 27-44 - $\mathrm{Mm}^{3}$ and $98-108 \mathrm{Mm}^{3}$, before reaching a cost of $40-45 \$ / \mathrm{m}^{3}$, where the supply curves became exponential. Central East EU, South-East and South-West are already close to the steep part of their curves and they can increase the mobilized volume of respectively 26-30 $\mathrm{Mm}^{3}$, 7-8 $\mathrm{Mm}^{3}$, 14-17 $\mathrm{Mm}^{3}$, before entering the exponential growth of costvolume ratio at $40-45 \$ / \mathrm{m}^{3}$ (Table 4 and Figure 2).

The total potential volume of logging residues in the "Reference scenario" is estimated to be 79 $\mathrm{Mm}^{3}$, corresponding to $13.5 \%$ of the roundwood potential volume. Of the total volume of log- 
ging residues, $45 \%$ is expected from the North of EU, 31\% from Central-West, $10 \%$ from Central-East, 10\% from South-West and 3\% from South-East. The cost supply curves for residues are generally linear in the cost range between 25 and $40 \$ / \mathrm{m}^{3}$ and became exponential after that threshold. In the whole EU, at a cost below $30 \$ / \mathrm{m}^{3}$, it would be possible to mobilize $10.1 \mathrm{Mm}^{3}$ (13\% of potential). If increasing the cost to $40 \$ / \mathrm{m}^{3}$, the mobilized volume reaches $53.3 \mathrm{Mm}^{3}$ ( $67 \%$ of potential).

If we consider a cost limit of $40-45 \$ / \mathrm{m}^{3}$, the largest amounts are expected form North and Central West EU, reaching 22-28 and 18-20 $\mathrm{Mm}^{3}$ respectively. If considering the same cost threshold, the amount mobilized in Central-East, South-East and South-West are expected to be respectively 6.9-8.1-, 1.7-1.9, 5.4-6.3 $\mathrm{Mm}^{3}$ respectively.

Table 4 >>

Figure $2>>>$

\section{EU Country level}

$\underline{\text { Roundwood }}$

Almost $60 \%$ of the total roundwood is produced in four countries, namely France, Sweden, Germany and Finland (Figure 3).

The lowest supply cost per SimU (intercept of cost supply curves) is observed in Poland, Czech Republic and Germany. Considering a maximum delivery cost of $20 \$ / \mathrm{m}^{3}$, the largest amount of delivered biomass was observed in Germany. If increasing the maximum delivery cost to 30 $\$ / \mathrm{m}^{3}$, the largest deliveries were observed in Germany and Sweden, significant amounts were also delivered in France, Poland, Finland, and Czech Republic. Considering a maximum cost of $40 \$ / \mathrm{m}^{3}$, the largest deliveries were expected in Germany, Sweden, France and Finland (Table $5)$.

Table 5

Figure 3

\section{Logging residues}

The countries with the largest potential were: Sweden, Finland, France and Germany. Countries with relevant contributions are also Spain and Poland (Figure 4).

The lowest supply costs per SimU (intercept of cost supply curve) were observed in Croatia, Czech Republic and Austria. For a maximum cost of $20 \$ / \mathrm{m}^{3}$, the volume of logging residues delivered to the industry would not be significant in any of the EU countries. If increasing the cost to $30 \$ / \mathrm{m}^{3}$, the largest delivery were observed in Germany, relatively high amounts are also 
delivered in Czech Republic and Austria. If considering a maximum cost of $40 \$ / \mathrm{m}^{3}$, the largest delivery were expected from Sweden, Finland and Germany (Table 6).Table 6 >>>

\section{Figure $4>>>$}

\section{Roadside costs}

If excluding the road transportation costs from the cost supply curves, it was observed that the production costs at the roadside were generally between 10 and $30 \$ / \mathrm{m}^{3}$ for roundwood, and between 15 and $30 \$ / \mathrm{m}^{3}$ for logging residues. At a cost below $15 \$ / \mathrm{m}^{3}$ it was possible to mobilize the largest volume of roundwood from Central-West and by Central-East EU. At roadside costs below $20 \$ / \mathrm{m}^{3}$ the Central-West and North of EU assumed a leading role (Figure 5).

At a cost below $25 \$ / \mathrm{m}^{3}$ it was possible to mobilize the largest volumes of logging residues from Central-West and Central-East EU. At a cost below $30 \$ / \mathrm{m}^{3}$ the North of EU and CentralWest became the regions with the largest supply (Figure 5).

\section{Figure $5>>>$}

\section{Sensitivity analysis}

In the Standardized Transportation alternative, if setting a limit of $30 \$ / \mathrm{m}^{3}$, it would be possible to mobilize $399 \mathrm{Mm}^{3}$ of roundwood (68\% of potential) in the EU. This is $12 \%$ more than in the Reference case. Thus, a downward shift of the curves is observed, meaning that generally the average transportation distances for roundwood in the Reference case were longer than $50 \mathrm{~km}$. The largest gain in cost competitiveness is observed for North of EU, especially if compared to Central-West due to higher load capacities in road transportation and relatively lower density of facilities assumed in the Reference case (Table 7). A significant gain in competitiveness is also observed for Central-East compared to Central-West (Figure 6).

In the Standardized Transportation, at a cost below $40 \$ / \mathrm{m}^{3}$, it would be possible to mobilize $73.3 \mathrm{Mm}^{3}$ of logging residues (93\% of potential), which is 38\% more than in the Reference. Also for logging residues, the standardization of transportation distances increased competiveness for North of EU and Central-East compared to the Central-West (Table 7 \& Figure 6).

In the Economic Growth, if setting a limit of $30 \$ / \mathrm{m}^{3}$, it would be possible to mobilize $291 \mathrm{Mm}^{3}$ of roundwood ( $50 \%$ of potential) in the EU, which is $6 \%$ less than in the Reference. With a cost increase to $40-45 \$ / \mathrm{m}^{3}$, the mobilized volume reached $461-501 \mathrm{Mm}^{3}$ (79-86 \% of potential), which is a 3-6\% less than in the Reference conditions. The increases in cost levels did not change the cost competitiveness between the regions. The main effect of the new cost levels was generally an upwards shift of the whole curves making less wood available as compared to the Reference (Table 7). The average increase of the intercepts for the curves in the whole EU was $0.5 \$ / \mathrm{m}^{3}$ (3.0\%), when compared to the Reference (Figure $7 \&$ Annex 12).

In the Economic Growth, it would be possible to mobilize $6.8 \mathrm{Mm}^{3}$ ( $9 \%$ of potential) of residues at cost below $30 \$ / \mathrm{m}^{3}$, and for a cost below $40-45 \$ / \mathrm{m}^{3}$ it is expected that a volume of $48-61$ $\mathrm{Mm}^{3}$ (60-78\% of potential) would be mobilized, thus a 2-7\% reduction of supply can be expected compared to the Reference scenario. As noticed for roundwood, also for logging residues 
the curves are generally shifted upwards. The average increase of the intercepts in the EU was $1.1 \$ / \mathrm{m}^{3}$ (5.2\%) compared to the Reference curves (Figure 7 \& Annex 12).

The total volume of roundwood in the Forestry Intensification alternative is estimated to be 685 $\mathrm{Mm}^{3}$, a $17 \%$ increase of total EU potential compared to the Reference scenario. Of this total potential, $37 \%$ is expected from Central-West countries, 31\% from the North of EU, $19 \%$ from Central-East, $10 \%$ from South-West and 3\% from South-East. Thus, the greatest increase of available volumes is expected from Central-East EU. In the whole EU, at a cost below $30 \$ / \mathrm{m}^{3}$, it would be possible to mobilize $301 \mathrm{Mm}^{3}$ (44\% of potential), that is $28 \mathrm{Mm}^{3}$ less than in the Reference curves. If increasing the cost limit to $40-45 \$ / \mathrm{m}^{3}$, the mobilized roundwood volume reaches $517-569 \mathrm{Mm}^{3}$ (76-83\% of potential). The greatest difference in volumes available at the different costs is expected in Central-East EU, where 15-35 and $37 \mathrm{Mm}^{3}$ more than in the Reference curves are available at a cost of 30-40 and $45 \$ / \mathrm{m}^{3}$ (Table 7). The intercepts of the cost supply curves for roundwood are similar to those in the Economic Growth (Figure 7 \& Annex 12).

The total potential volume of logging residues in the Forestry Intensification alternative is estimated to be $91 \mathrm{Mm}^{3}$, which is $15.6 \%$ larger than in the Reference scenario. Of this total volume, $42 \%$ is expected from the North of EU, 30\% from Central-West, $13 \%$ from Central-East, $12 \%$ from South-West and 3\% from South-East. The greatest increases of available volumes are expected from North and Central-East EU, where respectively 5.7 and $3.1 \mathrm{Mm}^{3}$ more than in the Reference case will be available. In the whole EU, at a cost threshold of $30 \$ / \mathrm{m}^{3}$, it would be possible to mobilize $8 \mathrm{Mm}^{3}$ (9\% of potential), that is $2 \mathrm{M} \mathrm{m}^{3}$ less than in the Reference curves. If increasing the cost to $40-45 \$ / \mathrm{m}^{3}$, the mobilized volume reached $55-70 \mathrm{Mm}^{3}$ (61-77 \% of potential). As noticed for roundwood, the greatest difference in volumes available at the different costs is expected in Central-East EU (Table 7). In this condition, the number of countries where logging residues can be delivered at a cost lower than $20 \$ / \mathrm{m}^{3}$ increased from 10 to 14 compared to the Reference case. However, for a maximum cost of $20 \$ / \mathrm{m}^{3}$, only marginal volumes of logging residues are delivered to the industry (Figure $7 \&$ Annex 12).

Figure $6>>>$

Figure 7

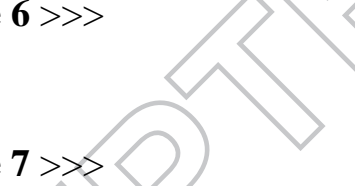

Table 7

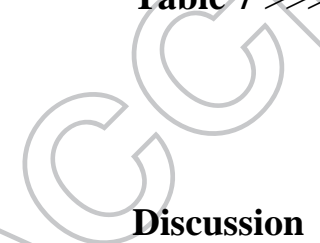

The results of our analyses show that there is potential to increase roundwood harvests and logging residue extraction in the EU28, but only in a few countries. In most European countries, the costs of logging residues extraction increase exponentially already on low levels of extraction, while roundwood can be harvested to a much larger extent with reasonable costs. The potential for increasing biomass mobilization varies largely between different countries, highlighting the importance of spatially explicit analyses and decisions. Our findings support the existing 
literature on the topic, and add on it by showing the cost-supply relation of roundwood harvests and logging residues extraction with an unprecedented spatial detail.

At costs below $30 \$ / \mathrm{m}^{3}$, a large share of roundwood (44-68\% of potential) but only a small share of logging residues (9-13\%) can be mobilized. In all countries, the mobilization of logging residues was found to be much more sensitive to changes in costs than mobilization of roundwood.

The economic potential of forest biomass harvest varied largely between the countries. At low supply costs (lower than $20 \$ / \mathrm{m}^{3}$ ), countries in East EU (Czech Republic and Poland) together with Germany would be able to mobilize the greatest share of roundwood because of respectively the low harvesting costs and the high density of industries. If higher costs are considered, Central Europe (Germany and France) and the Nordic Countries (Sweden and Finland), are able to mobilize large volumes at reasonable costs due to the large potentials of woody biomass per unit of land, high density of industries combined with efficient transportation. In other regions, costs increase strongly already with low levels of harvests, indicating a low economic potential for increased harvests. Similar results are seen also for extraction of logging residues, in this case the Nordic Countries (Sweden and Finland) assume a leading role, although relevant supply will not be possible at a cost lower than $20 \$ / \mathrm{m}^{3}$.

If willing to achieve larger volumes, countries in Central-East and South EU will require important infrastructural investments, in order to be cost competitive with Central-West Europe (Germany and France) (Figure 2). An economic growth in the European Union will reduce the roundwood volumes mobilized at the different costs by 3-6\% and the availability of residues will be reduced by $2-7 \%$. An intensification of forestry, by increasing the forests managed for production will considerably increase the amount of mobilized biomass at the different costs in the EU. This is especially prominent in countries in the East EU (Czech Republic, Poland).

The differences in cost levels between different countries are generally in line with the findings of Asikainen et al. (2008), who also showed that the Czech Republic and Poland are highly cost competitive for supply of logging residues in the EU. However, based on previous literature we were expecting that also other countries in the East EU and in the Baltics could deliver significant amounts of biomass at low cost levels (de Wit \& Faaij, 2010). This was not reflected in our findings. A possible explanation is that in our approach we adapted the interest rates for invested capitals to the risks incurred across country borders, which lead to higher capital costs for mechanized systems used in less stable economies. In the long term, it could be expected that the risk in the whole EU will converge, leading to higher competitiveness of countries with emerging economies. However, the combined index that we used for measuring risk for investments gives a forecast of only five years, and it will be difficult to speculate on risk development in a longer term. Another possible reason for the high cost incurred in Baltic States and East Europe is the low density of receiving industries, thus the development of industrial sector in these areas could lead to lower costs than in our calculations, as it is shown by the standardization of transportation distance and by the supply costs at the roadside.

The potentials of logging residues for the Nordic Countries in our study are in line with the technical achievable potentials presented recently by Routa et al. (2012), and Asikainen et al. (2008). Our study showed that it will be possible to mobilize residues at costs less than $20 \$ / \mathrm{m}^{3}$ only from forest units where whole tree harvesting systems are applied in Austria, Croatia, Czech Republic. However, these forests are located on slopes above 30\%, where the supply costs for roundwood usually exceed $40 \$ / \mathrm{m}^{3}$. For this reason, it would be relevant to combine the supply curves for roundwood with the one for residues. 
We used the purchasing power parity (PPP) ratio approach for adapting the cost of labor to the country borders. As a consequence in our study, a long term convergence for labor costs to a common level is assumed. A similar possible development for labor costs was also shown by de Wit \& Faaij (2010).

In this study, we did not consider social aspects connected to mobilization. In Verkerk et al. (2011), this aspect was also included, by assuming that the size of forest properties can influence the resource accessibility in the different countries. If including also this component, we can expect a reduction of supply compared to the presented results, as forest holdings in Europe are generally relatively small.

The selection of harvesting systems assigned to the forest units was based on a comparison of cost convenience between mechanized and labor intensive systems. However, also other criteria than economic ones can be used. One possible option would be to include also environmental criteria (c.f. Kühmaier \& Stampfer 2010, Dimou \& Malivisti 2014) and to consider also the evolution in the uses of current harvesting systems and implementation of new ones (Visser \& Stampfer 2015, Visser \& Berkett 2015).

In our approach, we used the largest cities in each of the countries as a proxy for calculation of transportation to the industries. While this matches reality to a certain degree, this assumption is also likely to lead to deviations in results compared to real locations of forest industries. However, the location of densely populated cities is expected to hold for longer time than the position of industries. In order to show the possible effect of higher density of wood industries (e.g. sawmills), the supply costs at the roadside and the costs at a standardized distance (50 km) were also included in this study.

Short run production costs were included in the model but also the costs for maintenance of existing forest infrastructures need to be included into a comprehensive analysis. However a specific mapping of density of infrastructural networks in relation to forests impacted by human activities can be obtained from deforestation maps (Hansen et al. 2013). Extraction distances (from stumps to roadside) are currently fixed in the calculation of efficiencies. This factor has a significant effect, and is relevant especially in hilly or mountainous areas (Spinelli et al. 2015). In our study, an initial adaptation for the EU was carried out using altitude classes.

In addition, in some of the countries, multimodal transportation by integration of trucks, trains and boat is expected to increase in the future. This could create some deviation from our results, however in the EU road transportation is still the most common mode of transport for woody biomass (Wolfsmayr \& Rauch, 2014). If considering the costs in the long run, also creation of new infrastructure must be included in the model.

Stumpage fees and compensation paid to the forest owner could be other relevant components of cost paid at the industry (c.f. Lundmark et al. 2015). However, in the present study we showed only costs which can be modeled in a geographically explicit way. As the stumpage price is connected to the concept of resource scarcity and difficult to model without a comprehensive framework where also demand and supply are included, this approach is considered as an important improvement for the future.

Our findings suggest that considerable increases in logging residue extraction will not be economically feasible within the EU without intensification of actively managed forests. Instead, use of roundwood and, as suggested by Lauri et al. 2014, by-products of the roundwoodprocessing industry will probably be more cost-efficient for satisfying the increasing forest biomass demand than expanding the extraction of logging residues within EU28. This is an im- 
portant and timely message for the political decision-makers, considering the intensive discussions about the role of forest biomass in bioeconomies, both a national and regional levels (Böttcher et al. 2012, Frank et al. 2016). It is also noteworthy that without considerable infrastructural investments in the Central East and South of the EU, most of the future supply for roundwood and residues will be possibly provided at reasonable costs mostly from Central and North EU.

\section{References}

Ackerman P, Belbo H, Eliasson L, de Jong A, Lazdins A, Lyons J. 2014. The COST model for calculation of forest operations costs, Int J For Eng 25: 75-81.

Alexandratos N, Bruinsma J. 2012 World Agriculture Towards 2030/2050 The 2012 Revision. ESA Working Paper no. 12-03. FAO: Rome.

Asikainen A, Liiri H, Peltola S, Karjalainen T, Laitila J. 2008. Forest energy potential in Europe (EU 27). Working Papers of the Finnish Forest Research Institute 69. 33 p.

Beltrami H. 2001. On the relationship between ground temperature histories and meteorological records: a report on the Pomquet station. Glob Planet Change 29: 327-348.

Binkley C, Dykstra D. 1987. Timber supply. In: Binkley CS, Dykstra DP, Kallio MJ (eds). The global forest sector: An analytical perspective. John Wiley \& Sons. pp. 508-533.

Brungberg T. 2014. Skogsbrukets kostnader 2014 [Internet]. Skogforsk: [cited 2016 Aug 1].

Available from http://www.skogforsk.se/kunskap/kunskapsbanken/2015/skogsbrukets-

kostnader-2014

Buongiorno J, Zhu S, Zhang D, Turner J, Tomberlin D. 2003. The global forest products model. Chichester: Elsevier.

Böttcher H, Verkerk PJ, Gusti M, Havlík P, Grassi G. 2012. Projection of the future EU forest $\mathrm{CO} 2$ sink as affected by recent bioenergy policies using two advanced forest management models. GCB Bioenergy 4: 773-783, doi: 10.1111/j.1757-1707.2011.01152.x

Chien Y, Arias AM. 2015. Lagging long-term wage growth [Internet]. Economic Synopses, Issue 14, 2015. [cited 2016 Aug 1]. Available at SSRN: http://ssrn.com/abstract=2646127

Daioglou V, Stehfest E, Wicke B, Faaij A, Mantau U, Saal U, Prins K, Steierer F, Lindner M, Van Vuuren PD. 2015 Projections of the availability and cost of residues from agriculture and forestry. GCB Bioenergy (2015) ISSN: 1757-1693. doi:10.1111/gcbb.12285

de Wit M, Faaij A. 2010. European biomass resource potential and costs. Biomass Bioenergy 34: 188-202.

Dimou V, Malivisti Z. 2014. Strategic decision model for the evaluation of timber harvesting systems. Int J For Eng 26: 146-157.

European Commission. 2006. European Soil Database (v. 2.0), raster version $1 \mathrm{~km} \times 1 \mathrm{~km}$. European Commission - DG Joint Research Centre, Ispra. [cited 2016 Aug 1]. Available at http://esdac.jrc.ec.europa.eu/content/european-soil-database-v20-vector-and-attribute-data 
EFSOS 2011. The European Forest Sector Outlook Study II. UNECE/FAO United Nations Publications Geneva September 2011, ISSN 1020-2269, 107 p.

European Commission. 2013. EU energy, transport and GHG emissions trends to 2050, Reference scenario 2013. Directorate-General for Energy, Directorate-General for Climate Action and Directorate-General for Mobility and Transport. ISBN 978-92-79-33728-4: Luxembourg: Publications Office of the European Union. doi: 10.2833/17897

European Commission. 2014. EU transport in figures. Statistical Pocketbook 2014. Publications Office of the European Union.

FAO. 2001. FRA 2000 Main Report. FAO Forestry Paper 140. Rome.

FAO 2014. State of the World's Forests 2014. Rome. E-ISBN 978-92-5-108270-6.

FE 2011. FOREST EUROPE, UNECE and FAO 2011: State of Europe's Forests 2011. Status and Trends in Sustainable Forest Management in Europe. Ministerial Conference on the Protection of Forests in Europe, 2011. ISBN 978-82-92980-05-7. Oslo Grøset Trykk AS. 337 pp.

ForeStat 2015. [Internet]. Production Quantity Roundwood 2013. [cited 2016 Aug 1] Available at http://faostat.fao.org/

Frank S, Böttcher H, Gusti M, Havlík P, Klaassen G, Kindermann G, Obersteiner M. 2016. Dynamics of the land use, land use change, and forestry sink in the European Union: the impacts of energy and climate targets for 2030. Climatic Change 1-14. doi: 10.1007/s10584-016-1729-7.

Galik CS, Abt R, Wu Y. 2009. Forest biomass supply in the Southeastern United StatesImplications for industrial roundwood and bioenergy production. J For 107: 69-77.

GIZ 2013. Deutche Gesellschaft fur Internationale Zusammenarbeit GmbH (Fuel Prices 2012).

Granhus A, Fjeld D. 2008. Time consumption of planting after partial harvests. Silva Fenn 42: 49-61.

Gusti M. 2010. An algorithm for simulation of forest management decisions in the global forest model. Artificial Intelligence 4: 45-49.

Gusti M, Kindermann G. 2011. An approach to modeling landuse change and forest management on a global scale. In: SIMULTECH-2011. Proceedings of 1st International Conference on Simulation and Modeling Methodologies, Technologies and Applications--Kacprzyk J, Pina N, Filipe J, eds. (2011) Noordwijkerhout, The Netherlands July 29 - 31 2011: SciTePress - Science and Technology Publications, Portugal. p. 180-185.

Hansen MC, Potapov PV, Moore R, Hancher M, Turubanova SA, Tyukavina A, Thau D, Stehman SV, Goetz SJ, Loveland TR, Kommareddy A, Egorov A, Chini L, Justice CO, Townshend J.R.G. 2013. High-resolution global maps of 21st-century forest cover change. Science 342: 850-853. doi: 10.1126/science.1244693

Havlík P, Schneider U, Schmid E, Böttcher H, Fritz S, Skalský R, Aoki K, Cara SD, Kindermann G, Kraxner F, Leduc S, McCallum I, Mosnier A, Sauer T, Obersteiner M. 2011. Global land-use implications of first and second generation biofuels targets. Energy Policy 39: 56905702.

Hock BK, Blomqvist L, Hall P, Jack M, Möller B, Wakelin SJ. 2012. Understanding forestderived biomass supply with GIS modelling, J Spat Sci 57: 213-232. 
International Country Risk Guide, ICRG, 5 year composite risk forecast. Copyright, The PRS Group, Inc. 1984 Present, [cited 2016 Aug 1] Available at https://www.prsgroup.com

Kindermann GE, McCallum I, Fritz S, Obersteiner M. 2008. A global forest growing stock, biomass and carbon map based on FAO statistics. Silva Fenn 42: 387-396.

Kindermann GE, Schörghuber S, Linkosalo T, Sanchez A, Rammer W, Seidl R, Lexer MJ. 2013. Potential stocks and increments of woody biomass in the European Union under different management and climate scenarios. Carbon Balance Manag 8:2 doi: 10.1186/1750-0680-8-2.

Kühmaier M, Stampfer K. 2010. Development of a multi-attribute spatial decision support system in selecting timber harvesting systems. Croat J For Eng 31: 75-88.

Lauri P, Havlik P, Kindermann G, Forsell N, Böttcher H, Obersteiner M. 2014. Woody biomass energy potential in 2050. Energy Policy 66: 19-31.

Lundmark R, Atthanassiadis D, Wetterlund E. 2015. Supply assessment of forest biomass - A bottom-up approach for Sweden. Biomass Bioenergy 75: 213-226.

Mantau U, Saal U, Prins K, Steierer F, Lindner M, Verkerk H, Eggers J, Leek N, Oldenburger J, Asikainen A, Anttila P. 2010: EUwood - Real potential for changes in growth and use of EU forests. Final report. Call for tenders No. TREN/D2/491-2008. EUwood. Hamburg/Germany, June 2010. 160 p.

Muhammad A, Seale J, Meade B, Regmi A. 2011. International evidence on food consumption patterns: An update using 2005 International Comparison Program Data. Technical Bulletin (1929) USDA-ERS. Washington, D.C.

Nordfjell T, Bacher M, Eriksson L, Kadlec J, Stampfer K, Suadicani K, Suwala M, Talbot B. 2004. Operational factors influencing the efficiency in conversion. In Spiecker H, Hansen J, Klimo E, Skovsgaard JP, Sterba H, Von Teuffel K. (eds.) Norway spruce conversion-options and consequences. European Forest Institute Research Report 18. Leiden-Boston: Brill.

Nurmi J. 2007. Recovery of logging residues for energy from spruce (Pices abies) dominated stands. Biomass Bioenergy 31: 375-380.

Open street map. [cited 2016 Aug 1] Available at http://www.openstreetmap.org

Platts 2013. World electric power plants database, 2013. [cited 2016 Aug 1] Available at http://www.platts.com/products/world-electric-power-plants-database

Repo A, Böttcher H, Kindermann G, Liski J. (2015), Sustainability of forest bioenergy in Europe: land-use-related carbon dioxide emissions of forest harvest residues. GCB Bioenergy 7: 877-887. doi:10.1111/gcbb.12179

RISI, Pulp and Paper mill Asset Database. [cited 2016 Aug 1] Available at http://www.risiinfo.com/service/mill-data-costs/asset-database

Routa J, Asikainen A, Björheden R, Laitila J, Röser D. 2013. Forest energy procurement: State of the art in Finland and Sweden. WIREs Energy Environ 2: 602-613.

Sikkema R, Faaij APC, Ranta T, Heinimo J, Gerasimov YY, Karjalainen T, Nabuurs GJ. 2014. Mobilization of biomass for energy from boreal forests in Finland \& Russia under present sustainable forest management certification and new sustainability requirements for solid biofuels. Biomass Bioenergy 71: 23-36. 
Siry JP, Greene WD, Harris TG, Izlar RL, Hamsley A, Eason KE, Tye T, Baldwin SS, Hydahl C. 2006. Wood supply chain efficiency and fiber cost: What can we do better? For Prod J 56: 410.

Skalsky R, Tarasovicova Z, Balkovic J, Schmid E, Fuchs M, Moltchanova E, Kindermann G, Scholtz P. 2008. Geo-bene global database for bio-physical modeling v. 1.0. Concepts, methodologies and data. Technical Report, IIASA, Laxenburg.

Spinelli R, Magagnotti N, Pari L, De Francesco F. 2015. A comparison of tractor-trailer units and high-speed forwarders used in Alpine forestry. Scand J For Res 30: 470-477, doi: 10.1080/02827581.2015.1012113

Teobaldelli M, Somogyi Z, Migliavacca M, Usoltsev VA. 2009. Generalized functions of biomass expansion factors for conifers and broadleaved by stand age, growing stock and site index. For Ecol Manage 257: 1004-1013.

The World Bank 2014 Tariff rate, applied, simple mean, manufactured products (\%). [cited 2016 Aug 1] Available at http://data.worldbank.org/indicator/

The World Bank 2014. PPP conversion factor, GDP (LCU per international \$). [cited 2016 Aug 1] Available at http://data.worldbank.org/indicator/

The World Bank 2014. Price level ratio of PPP conversion factor (GDP) to market exchange rate. [cited 2016 Aug 1] Available at http://data.worldbank.org/indicator/

The World Bank Group 2014. Economy Snapshots, paying-taxes. [cited 2016 Aug 1] Available at http://www.doingbusiness.org/data/exploreeconomies

Verkerk PJ, Anttila P, Eggers J, Lindner M, Asikainen A. 2011. The realizable potential supply of woody biomass from forests in the European Union. For Ecol Manage 261: 2007-2015.

Verkerk PJ, Levers C, Kuemmerle T, Lindner M, Valbuena R, Verburg PH, Zudin S. 2015. Mapping wood production in European forests. For Ecol Manage 357: 228-238. http://dx.doi.org/10.1016/j.foreco.2015.08.007

Visser R, Berkett H. 2015. Effect of terrain steepness on machine slope when harvesting. Int J For Eng 26: 1-9.

Visser R, Stampfer K. 2015. Expanding ground-based harvesting onto steep terrain: A review. Croat J For Eng 36: 321-331.

WDPA Consortium. 2004. World Database on Protected Areas. Copyright World Conservation Union (IUCN) and UNEP-World Conservation Monitoring Centre (UNEP-WCMC). [cited 2016 Aug 1] Available at http://www.protectedplanet.net

Wihersaari M. 2005. Greenhouse gas emissions from final harvest fuel chip production in Finland. Biomass Bioenergy 28: 435-443.

Wolfsmayr UJ, Rauch P. 2014. The primary forest fuel supply chain: A literature review. Biomass Bioenergy 60: 203-221.

WorldClim- Global Climate Data Free climate data for ecological modeling and GIS. Mean temperature map 30 arc-seconds. [cited 2016 Aug 1] Available at http://www.worldclim.org/version1 
Yemshanov D, McKenney DW, Fraleigh S, McConkey B, Huffman T, Smith S. 2014. Cost estimates of post harvest forest biomass supply for Canada. Biomass Bioenergy 69: 80-94.

\section{Aknowledgements}

The Kempe Foundation "Kempestiftelserna" of Sweden is acknowledged for financial support under the post doctoral funding scheme SKM-1336. This study was financially supported also by the Research Programme Future Forests. Future Forests is a multi-disciplinary research programme supported by the Foundation for Strategic Environmental Research (MISTRA), the Swedish Forestry Industry, the Swedish University of Agricultural Sciences (SLU), Umeå University, and the Forestry Research Institute of Sweden (Skogforsk). We are grateful to the experts involved in the global benchmarking exercise for a cross-border adaptation of forest operation's costs. We would like to thanks our colleagues Dr. Pekka Lauri and Dr. Stefan Frank for their professional advices.

Table 1. EU 28 forestry Regions defined according to Forest Europe (2011).

\begin{tabular}{|c|c|}
\hline Region & Countries \\
\hline North Europe & ark, Estonia, Finland, Latvia, Lithuania, \\
\hline Central-East Europe & Republic, Hungary, Poland, Romania, \\
\hline Central-West Europe & $\begin{array}{l}\text { Austria, Belgium, France, Germany, Ireland, } \\
\text { Luxemburg, Netherlands, United Kingdom }\end{array}$ \\
\hline South-East Europe & Bulgaria, Croatia, Cyprus, Greece, Slovenia \\
\hline Sc & Italy, Portugal, Spain \\
\hline
\end{tabular}

Table 2: Selected forest harvesting and road transportation systems for roundwood and logging residues.

\begin{tabular}{|c|c|c|c|c|c|c|c|c|c|c|}
\hline & & jundw & $(\mathrm{b})$ & & & & Logg & Resid & & \\
\hline 焉 & 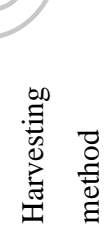 & 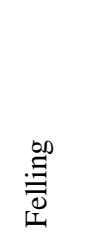 & 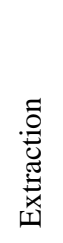 & $\begin{array}{l}\text { 泀 } \\
\text { 胥 }\end{array}$ & 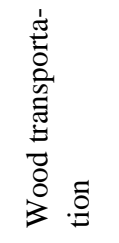 & 尝 & 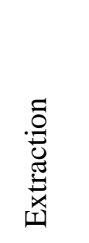 & 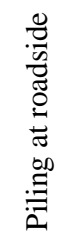 & 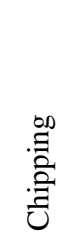 & 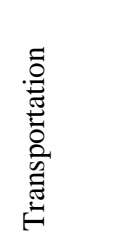 \\
\hline 1 & CTL & HA & FO & --- & TR WD & $\mathrm{HA}_{\mathrm{LR}}$ & FO $_{L R}$ & --- & $\mathrm{CH}$ & TRWC \\
\hline 2 & CTL & HA & FT & --- & TR WD & $\mathrm{HA}_{\mathrm{LR}}$ & $\mathrm{FT}_{\mathrm{LR}}$ & --- & $\mathrm{CH}$ & TR WC \\
\hline 3 & CTL & MFP & FO & -- & TR WD & MFPLR $_{\text {L }}$ & FO $_{L R}$ & --- & $\mathrm{CH}$ & TR WC \\
\hline 4 & CTL & MFP & FT & --- & TR WD & $\mathrm{MFP}_{\mathrm{LR}}$ & $\mathrm{FT}_{\mathrm{LR}}$ & --- & $\mathrm{CH}$ & TR WC \\
\hline
\end{tabular}




\begin{tabular}{llllll|lllll}
5 & CTL & MFP & SKL & --- & TR WD & --- & --- & -- & --- & --- \\
6 & CTL & MFP & CYL & --- & TR WD & --- & --- & --- & --- & -- \\
7 & WT & MF & SKW & PCH & TR WD & --- & --- & PCH & CH & TR WC \\
8 & WT & MF & SKW & PCM & TR WD & -- & --- & PCM & CH & TR WC \\
9 & WT & MF & CYW & PCH & TR WD & --- & --- & PCH & CH & TR WC \\
10 & WT & MF & CYW & PCM & TR WD & --- & --- & PCM & CH & TR WC \\
\hline
\end{tabular}

$\mathrm{CTL}=$ cut to length, $\mathrm{WT}=$ whole tree. If System 4, 5, 6 is applied $>$ No extraction of logging residues is considered. $\mathrm{HA}$ = felling and processing with single grip harvester, HALR= piling logging residues with single grip harvester, MFP= motor-manual felling with chainsaw, MFPLR= motor-manual piling logging residues, $\mathrm{MF}=$ motor-manual felling and processing with chainsaw, $\mathrm{FO}=$ forwarding roundwood to roadside with a forwarder, FOLR= forwarding logging residues with a forwarder, FT= extraction to roadside of roundwood with a farm tractor, FTLR= extraction to roadside of logging residues with a farm tractor, $\mathrm{SKL}=$ skidding logs with a skidder, $\mathrm{SKW}=$ skidding whole trees with a skidder, $\mathrm{CYL}=$ cable yarding roundwood logs, $\mathrm{CYW}=$ cable yarding whole trees, $\mathrm{PCH}=$ Mechanized processing at the roadside (crosscutting and delimbing) with excavator mounted processor head, PCM $=$ motor-manual processing at the roadside (cross-cutting and delimbing) with chainsaw, $\mathrm{PCH}_{\mathrm{LR}}=$ piling residues at the roadside with processor, $\mathrm{PCM}_{\mathrm{LR}}=$ piling residues at the roadside in motor-manual processing, $\mathrm{CH}=$ Chipping logging residues, TR WD = transportation of roundwood with a truck and trailer unit, TR WC $=$ transportation of chipped logging residues with a container truck and trailer unit. 
Table 3. Technical restrictions applied in the selection of forest equipment/machinery.

\begin{tabular}{lccc}
\hline Operation & Tree diameter (DBH, cm) & Slope (\%) & Soil bearing capacity \\
& & & \\
\hline HA & $0-50 \mathrm{c} / 40 \mathrm{~b}$ & $0-30$ & - \\
MF & No restriction & $0-100$ & - \\
MFP & No restriction & $0-100$ & No restriction \\
FO & - & $0-30$ & Not applicable on unfrozen peatland \\
FT & - & $0-30$ & No restriction \\
SKL & - & $0-50$ & No restriction \\
SKW & - & $0-50$ & No restriction \\
CYL & - & $0-100$ & No restriction \\
CYW & - & $0-100$ & - \\
PCH & $0-70 c / 60 b$ & - & - \\
PCM & No restriction & - & \\
\hline C=conifers; b=broadleaves & &
\end{tabular}

Table 4. Mobilized amounts of roundwood and logging residues in the 5 European Regions according to current production and in case of three different cost thresholds.

\begin{tabular}{|c|c|c|c|c|c|c|}
\hline \multirow[b]{4}{*}{$\underline{\text { Roundwood }}$} & \multicolumn{5}{|c|}{ Mobilized amount $\left(\mathrm{Mm}^{3}\right)$} & \multirow{3}{*}{ Total } \\
\hline & North & \multicolumn{2}{|c|}{ Central } & & & \\
\hline & & East & West & & West & \\
\hline & & & & & & \\
\hline Current $^{1}$ & 134.0 & 59.6 & & 7.1 & 11.5 & 310.8 \\
\hline Cost $35 \$ / \mathrm{m}^{3}$ & 136.4 & 80. & & 11.8 & 19.4 & 423.7 \\
\hline Cost $40 \$ / \mathrm{m}^{3}$ & .8 & 86.0 & 5.9 & 13.7 & 25.1 & 481.5 \\
\hline Cost $45 \$ / \mathrm{m}^{3}$ & & 90.0 & 206.6 & 14.6 & 28.7 & 518.3 \\
\hline$\Delta 35-40 \$ / \mathrm{m}^{3}$ & 24.4 & 5.7 & 20.1 & 1.9 & 5.7 & 57.8 \\
\hline$\Delta 40-45 \$ / 1$ & 17.6 & 4.0 & 10.7 & 0.9 & 3.6 & 36.8 \\
\hline Cost & 9.4 & 5.0 & 12.2 & 1.1 & 3.9 & 31.6 \\
\hline $\operatorname{Cost} 40 \$ / \mathrm{m}^{3}$ & 21.7 & 6.9 & 17.6 & 1.7 & 5.4 & 53.3 \\
\hline Cost $45 \$ / \mathrm{m}^{3}$ & 28.4 & 8.1 & 20.3 & 1.9 & 6.3 & 65.0 \\
\hline$\Delta 35-40 \$ / \mathrm{m}^{3}$ & 12.3 & 1.9 & 5.4 & 0.6 & 1.5 & 21.7 \\
\hline$\Delta 40-45 \$ / \mathrm{m}^{3}$ & 6.7 & 1.2 & 2.7 & 0.2 & 0.9 & 11.7 \\
\hline
\end{tabular}

${ }^{1}$ Current amount mobilized according to FAOSTAT (2013) 
Table 5. Descriptive statistics of the cost supply curve for roundwood.

\begin{tabular}{|c|c|c|c|c|c|}
\hline & 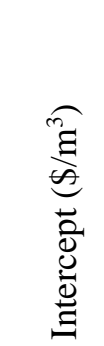 & 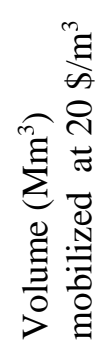 & 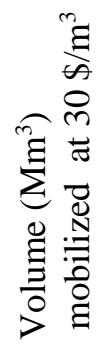 & 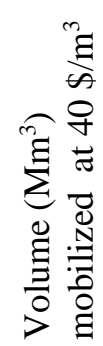 & 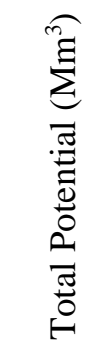 \\
\hline Austria & 15.34 & 2.3 & 8.1 & 12.7 & 20.0 \\
\hline Belgium & 18.14 & 0.3 & 4.9 & 5.8 & 5.8 \\
\hline Bulgaria & 14.98 & 1.3 & 3.7 & 5.3 & 6.3 \\
\hline Croatia & 15.27 & 1.4 & 3.4 & 5.2 & 6.2 \\
\hline Cyprus & 24.74 & 0.0 & 0.0 & 0.0 & 0.0 \\
\hline Czech & 13.45 & 12.8 & 20.0 & 20.2 & 20.3 \\
\hline Denmark & 17.22 & 0.9 & 2.7 & 3.1 & 3.1 \\
\hline Estonia & 16.89 & 0.6 & 5.3 & 9.6 & 10.7 \\
\hline Finland & 20.00 & 0.0 & 32.1 & 54.5 & 75.3 \\
\hline France & 18.05 & 0.2 & 38.3 & 78.4 & 98.4 \\
\hline Germany & 14.49 & 33.8 & 79.9 & 84.2 & 84.9 \\
\hline Greece & 26.88 & 0.0 & 0.1 & 0.3 & 1.6 \\
\hline Hungary & 15.44 & 1.3 & 5.1 & 7.4 & 7.9 \\
\hline Ireland & 16.74 & 0.2 & 1.1 & 2.2 & 3.4 \\
\hline Italy & 19.98 & 0.1 & 4.2 & 7.0 & 14.1 \\
\hline Latvia & 21.78 & 0.0 & 4.7 & 9.5 & 12.4 \\
\hline Lithuania & 15.96 & 0.8 & 4.4 & 6.3 & 6.9 \\
\hline Netherlands & 15.81 & & 1.0 & 1.0 & 1.1 \\
\hline Poland & 12.71 & 11.2 & 34.3 & 40.1 & 40.3 \\
\hline Portugal & 19.62 & 0.1 & 6.7 & 10.5 & 12.3 \\
\hline Romania & 17.32 & 0.9 & 5.8 & 12.3 & 16.6 \\
\hline Slovakia & 17.55 & 0.6 & 3.5 & 6.1 & 7.7 \\
\hline Slovenia & 16.21 & 0.4 & 2.6 & 2.8 & 3.0 \\
\hline Spain & 23.38 & 0.0 & 1.7 & 7.7 & 22.5 \\
\hline Sweder & 18.51 & 1.2 & 47.5 & 78.7 & 89.4 \\
\hline UK & 16.37 & 2.0 & 8.9 & 11.5 & 14.2 \\
\hline
\end{tabular}

Table 6. Descriptive statistics of the cost supply curve for logging residues. 


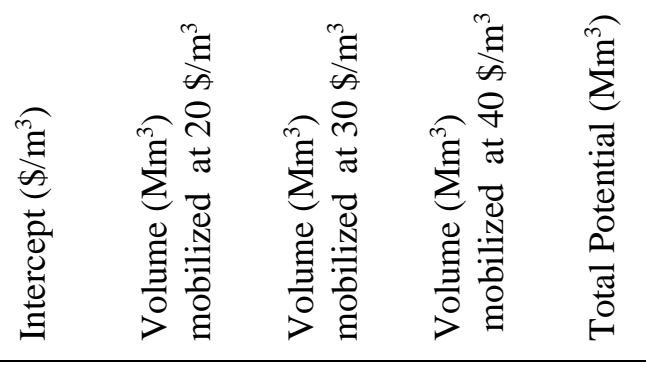

\begin{tabular}{|c|c|c|c|c|c|}
\hline Austria & 18.30 & 0.0 & 1.0 & 1.8 & 2.0 \\
\hline Belgium & 26.20 & 0.0 & 0.0 & 0.5 & 0.5 \\
\hline Bulgaria & 20.40 & 0.0 & 0.3 & 0.8 & 0.9 \\
\hline Croatia & 16.70 & 0.0 & 0.2 & 0.5 & 0.9 \\
\hline Cyprus & 18.70 & 0.0 & 0.0 & 0.0 & 0.0 \\
\hline Czech & 17.20 & 0.0 & 1.2 & 2.1 & 2.1 \\
\hline Denmark & 27.00 & 0.0 & 0.2 & 0.4 & 0.4 \\
\hline Estonia & 25.60 & 0.0 & 0.1 & 1.2 & 2.0 \\
\hline Finland & 29.00 & 0.0 & 0.3 & 9.0 & 13.6 \\
\hline France & 18.40 & 0.0 & 0.3 & 5.5 & 10.9 \\
\hline Germany & 19.20 & 0.0 & 2.5 & 7.7 & 8.1 \\
\hline Greece & 19.20 & 0.0 & 0.0 & 0.1 & 0.2 \\
\hline Hungary & 22.80 & 0.0 & 0.4 & 1.2 & \\
\hline Ireland & 23.60 & 0.0 & 0.0 & & 0.5 \\
\hline Italy & 18.80 & 0.0 & 0.6 & & 1.8 \\
\hline Latvia & 29.30 & 0.0 & & 0.6 & 1.8 \\
\hline Lithuania & 23.80 & 0.0 & & 0.9 & 1.5 \\
\hline Netherlands & 28.00 & & & 0.1 & 0.1 \\
\hline Poland & 19.40 & & & 2.5 & 3.4 \\
\hline Portugal & 18.40 & & & 1.4 & 1.8 \\
\hline Romania & 0.40 & 0.0 & 0.1 & 0.7 & 1.3 \\
\hline Slovakia & 2.80 & 0.0 & 0.1 & 0.4 & 0.7 \\
\hline Slovenia & & 0.0 & 0.1 & 0.3 & 0.3 \\
\hline Spain & & 0.0 & 0.7 & 2.3 & 4.1 \\
\hline Sweden & & 0.0 & 0.0 & 9.7 & 15.8 \\
\hline & 21.20 & 0.0 & 0.6 & 1.8 & 2.4 \\
\hline
\end{tabular}

Table 7. Difference of supply volumes in the Economic Growth and Forest Intensification alternatives in comparison to the Reference cost supply curves.

\begin{tabular}{lllllll}
\hline North & \multicolumn{4}{c}{ Central } & \multicolumn{3}{c}{ South } \\
\cline { 2 - 6 }
\end{tabular}

Standardized Transportation

Roundwood 


\begin{tabular}{|c|c|c|c|c|c|}
\hline Cost $30 \$ / \mathrm{m}^{3}$ & 33.6 & 16.9 & 13.3 & 3.9 & 3.1 \\
\hline Cost $35 \$ / \mathrm{m}^{3}$ & 23.0 & 10.8 & 18.8 & 2.6 & 3.7 \\
\hline Cost $40 \$ / \mathrm{m}^{3}$ & 14.9 & 6.5 & 8.3 & 1.1 & 2.0 \\
\hline Cost $45 \$ / \mathrm{m}^{3}$ & 12.6 & 2.7 & 4.0 & 0.4 & 1.8 \\
\hline \multicolumn{6}{|c|}{$\underline{\text { Standardized Transportation }}$} \\
\hline \multicolumn{6}{|c|}{ Residues } \\
\hline Cost $30 \$ / \mathrm{m}^{3}$ & -0.1 & -0.5 & -2.2 & 0.8 & 0.5 \\
\hline Cost $35 \$ / \mathrm{m}^{3}$ & 9.4 & 3.8 & -2.2 & 1.1 & 0.1 \\
\hline Cost $40 \$ / \mathrm{m}^{3}$ & 12.9 & 2.0 & 2.8 & 0.6 & 1.7 \\
\hline Cost $45 \$ / \mathrm{m}^{3}$ & 6.4 & 0.8 & 2.9 & 0.4 & \\
\hline \multicolumn{6}{|l|}{ Economic growth } \\
\hline \multicolumn{6}{|l|}{ Roundwood } \\
\hline Cost $30 \$ / \mathrm{m}^{3}$ & -17.8 & -5.8 & -11.8 & -1.1 & -1.2 \\
\hline Cost $35 \$ / \mathrm{m}^{3}$ & -10.0 & -3.9 & -11.6 & & -2.4 \\
\hline Cost $40 \$ / \mathrm{m}^{3}$ & -7.4 & -2.6 & -7.1 & -0.9 & -2.2 \\
\hline Cost $45 \$ / \mathrm{m}^{3}$ & -5.7 & -2.2 & & -0.6 & -2.2 \\
\hline \multicolumn{6}{|l|}{ Economic growth } \\
\hline Cost $30 \$ / \mathrm{m}^{3}$ & -0.6 & -0.8 & & -0.2 & -0.4 \\
\hline Cost $35 \$ / \mathrm{m}^{3}$ & -3.1 & -0.8 & -1.8 & -0.2 & -1.0 \\
\hline Cost $40 \$ / \mathrm{m}^{3}$ & -2.6 & -0.9 & -1.3 & -0.2 & -0.7 \\
\hline Cost $45 \$ / \mathrm{m}^{3}$ & -1.7 & & -0.9 & -0.1 & -0.6 \\
\hline \multicolumn{6}{|l|}{ Intensification } \\
\hline \multicolumn{6}{|l|}{ Roundwood } \\
\hline Total available volume & 16.8 & 40.1 & 22.7 & 3.9 & 16.7 \\
\hline Cost $30 \$ / \mathrm{m}^{3}$ & $340-2-2 \cdot$ & 15.4 & -6.8 & -1.0 & -1.6 \\
\hline Cost $35 \$ / \mathrm{m}^{3}$ & & 27.6 & -0.3 & 0.1 & -0.5 \\
\hline Cost $40 \$ / \mathrm{m}^{3}$ & & 34.8 & 8.2 & 0.4 & 0.6 \\
\hline Cost $45 \$ / \mathrm{m}^{3}$ & 2 & 37.1 & 10.9 & 1.6 & 3.6 \\
\hline \multicolumn{6}{|l|}{ Residues } \\
\hline$\frac{\text { Residues }}{\text { Total available }}$ & 5.7 & 3.1 & 2.5 & 0.4 & 3.0 \\
\hline Cost $30 \$ / \mathrm{m}^{3}$ & -0.6 & -0.4 & -0.9 & -0.1 & 0.0 \\
\hline Cost $35 \$ / \mathrm{m}^{3}$ & -2.7 & 0.9 & -0.4 & 0.0 & -0.1 \\
\hline Cost $40 \$ / \mathrm{m}^{3}$ & -1.5 & 2.1 & 0.5 & 0.1 & 0.6 \\
\hline Cost $45 \$ / \mathrm{m}^{3}$ & 0.2 & 2.8 & 1.2 & 0.2 & 0.9 \\
\hline
\end{tabular}

Figure 1: Decisional flowchart for assignment of harvesting systems to SimU (the descriptions of harvesting systems are given in Table 2).

Figure 2. Cost supply curves for roundwood (on the left) and logging residues (on the right), $\mathrm{x}$ axis=yearly amount $\left(\mathrm{M} \mathrm{m}^{3}\right)$, y axis= marginal supply cost at the industry gate $\left(\$ / \mathrm{m}^{3}\right)$. The dots on the curves for roundwood represent the current amounts mobilized according to FAOSTAT (2013).

Figure 3. Cost supply curves for roundwood logs in the EU 28 countries, $x$ axis=yearly amount $\left(\mathrm{M} \mathrm{m}^{3}\right)$, y axis= marginal supply cost at the industry gate $\left(\$ / \mathrm{m}^{3}\right)$ 
Figure 4. Cost supply curves for logging residues (delivered as wood chips) in the EU 28 countries, $\mathrm{x}$ axis=yearly amount $\left(\mathrm{M} \mathrm{m}^{3}\right)$, y axis= marginal supply cost at the industry gate $\left(\$ / \mathrm{m}^{3}\right)$.

Figure 5. Cost supply curves at roadside (i.e. excluding road transportation) for roundwood (on the left) and logging residues (on the right), $\mathrm{x}$ axis=yearly amount $\left(\mathrm{M} \mathrm{m}^{3}\right), y$ axis= marginal supply cost at the roadside $\left(\$ / \mathrm{m}^{3}\right)$.

Figure 6. Cost supply curves for roundwood (on the left) and logging residues (on the right), $\mathrm{x}$ axis=yearly amount $\left(\mathrm{M} \mathrm{m}^{3}\right)$, y axis= marginal supply cost at the industry gate $\left(\$ / \mathrm{m}^{3}\right)$ in the Reference (solid lines) and in the Standardized Transportation (dashed lines) alternative.

Figure 7. Cost supply curves for roundwood (on the left) and logging residues (on the right), $x$ axis=yearly amount $\left(\mathrm{M} \mathrm{m}^{3}\right)$, y axis= marginal supply cost at the industry gate $\left(\$ / \mathrm{m}^{3}\right)$ in the Reference (solid lines), Economic Growth (dashed lines) and Forestry Intensification (dotted lines) alternatives. The shadowed areas represent the expected variations in each of the EU Regions. 


\section{Annex 1. Time consumption models}

\section{Felling and processing with single grip harvester (HA)}

$T C=$ time consumption $\left(\mathrm{PMmin} / \mathrm{m}^{3}\right)$

Parameters: $V s=$ stem volume ( $\mathrm{m}^{3}$ over bark), $\mathrm{S}=$ slope $(\%)$, Clearcut (Final Felling) $=\mathrm{FF}$, Conifers $=\mathrm{C}$

The TC for conifers (C) is based on Nurminen et al. (2006) model for spruce, the slope correction factor is based on Hartsough et al. (2001) regression for not self-leveling cabin machinery.

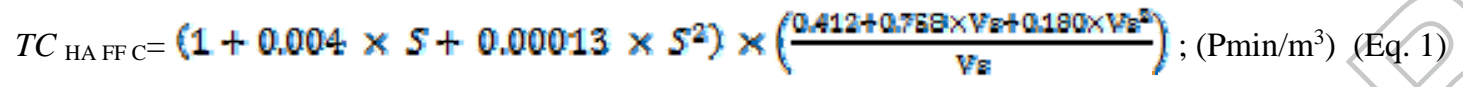

In case of broadleaves (B), the TC in Eq. 1 was increased of $0.45 \mathrm{Pmin} / \mathrm{m}^{3}$, the coefficient was calculated according to the extra processing time found in Spinelli et al. (2010), when comparing harvesters processing broadleaves and conifers

$$
T C_{\text {HA FFB }}=\left(1+0.004 \times S+0.00013 \times S^{2}\right) \times\left(\left(\frac{0.412+0.789 \times V_{z}+0.190 \times V_{z}^{2}}{V_{z}}\right)+0.45\right) ;\left(\mathrm{Pmin} / \mathrm{m}^{3}\right)(\text { Eq. 2) }
$$

In thinning (TH), it was assumed that the TC increases compared to FF, according to the differences between two models developed for a single grip harvester in FF and TH (Eriksson \& Lindroos 2014), the relation found was: TC $\mathrm{TH}=1.28 \mathrm{TC}_{\mathrm{FF}}$.

$$
T C_{\text {HA TH }}=1.28 \times\left(\left(1+0.004 \times \mathrm{S}+0.00013 \times S^{2}\right) \times\left(\frac{60}{(4.067+70.628 \times V 8-18.607 \times V z=}\right)\right) ;\left(\mathrm{Pmin} / \mathrm{m}^{3}\right) \text { (Eq. }
$$

3)

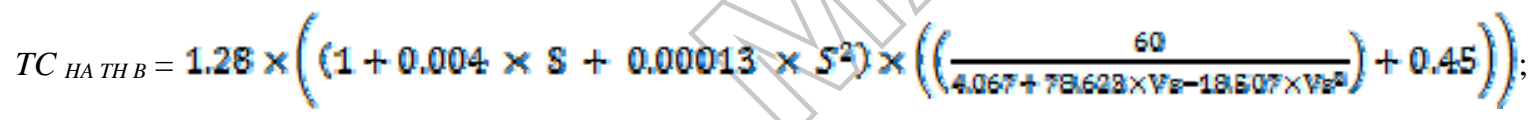

$\left(\operatorname{Pmin} / \mathrm{m}^{3}\right) \quad$ (Eq. 4)

\section{Motor-manual felling with chainsaw (MF)}

Parameters: Vs= stem volume $\left(\mathrm{m}^{3}\right.$ over bark), $\mathrm{S}=$ slope $(\%)$

The TC for felling conifers (C) trees in FF with a chainsaw was based on Erni et al. (2003), the effect of slope was exponentially modeled as a simplification of the original model parameters.

$$
T C_{\mathrm{MFFF}}=1.481 \times e^{\left(-0.9108+2.4291 \times \mathrm{Fg}^{-0.456}\right)} \times\left(1+0.0021 \times e^{(0.0688 \times s)}\right) ;\left(\mathrm{Pmin} / \mathrm{m}^{3}\right)(\text { Eq. 5) }
$$

In the case of broadleaves (B), the TC was based on (Erni et al. 2003) and the model for broadleaves was applied:

$T C_{\mathrm{MFFB}}=0.00175 \times e^{\left(1.0+6.9216 \times \mathrm{V}^{-0.0654}\right)} \times\left(1+0.0021 \times e^{(0.0689 \times S)}\right) ;\left(\mathrm{Pmin} / \mathrm{m}^{3}\right)(\mathrm{Eq} .6)$

In thinning (TH), it was assumed that TC in FF (Eq. 10-11) would increase by $20 \%$ according to the difference in Lotz et al. (1997) models, that is $\mathrm{TC}_{\mathrm{TH}}=1.2 \mathrm{TC}_{\mathrm{FF}}$ (i.e. considering removal stem volume of $0.2 \mathrm{~m}^{3}$ and a removal of $40 \%$ in basal area).

$T_{M F T H C}=1.20 \times\left(1.481 \times e^{\left(-0.5108+2.4291 \times V_{s}-0.4569\right)} \times\left(1+0.0021 \times e^{(0.0689 \times s)}\right)\right) ;\left(\mathrm{Pmin} / \mathrm{m}^{3}\right)(\mathrm{Eq}$. 7)

$$
T C_{M F T H B}=1.20 \times\left(0.00175 e^{\left(1.0+6.9216 \times V^{-0.0654}\right)} \times\left(1+0.0021 \times \theta^{(0.0689 \times S)}\right)\right) ;\left(\mathrm{Pmin} / \mathrm{m}^{3}\right)(\text { Eq. 8) }
$$


The TC for felling and processing with chainsaw was based on the model of Stampfer et al. (2002) (i.e. no accumulation of branches). The percentage of branches (on whole tree volume) was fixed to $20 \%$ for broadleaves and $25 \%$ for conifers in FF and respectively to 25 and 30\% in TH (c.f. Lehtonen et al. 2004). The effect of slope was exponentially modeled as in Eq. 5-8.

$$
\begin{aligned}
& T C_{\text {MFP FF C }}=\frac{0.75}{V s} \times\left(\left(3.3229+9.8999 \times\left(\frac{V g}{0.75}\right)^{0.7}\right) \times\left(1+0.0021 \times e^{0.0688 \times s}\right)\right)\left(\mathrm{Pmin} / \mathrm{m}^{3}\right)(\mathrm{Eq} .9) \\
& T C_{\text {MFP FF B }}=\frac{0.90}{V_{s}} \times\left(\left(3.3229+9.3564 \times\left(\frac{V_{s}}{0.90}\right)^{0.7}\right) \times\left(1+0.0021 \times \theta^{0.9658 \times s}\right)\right)\left(\mathrm{Pmin} / \mathrm{m}^{3}\right)(\mathrm{Eq} .10)
\end{aligned}
$$

In thinning (TH), it was assumed that TC in FF would increase by $20 \%$, according to the differences measured in Lotz et al. (1997), that is $\mathrm{TC}_{\mathrm{TH}}=1.2 \mathrm{TC}_{\mathrm{FF}}$ (.e. considering removal stem volume of $0.2 \mathrm{~m}^{3}$ and a removal of $40 \%$ in basal area).

$$
T C_{\text {MFP TH }}=1.20 \times\left(\frac{0.70}{V s} \times\left(\left(3.3229+10.4434 \times\left(\frac{V_{s}}{0.70}\right)^{0.7}\right) \times(1+0.0021 \times 0.0658 \times 5)\right)\right)
$$

$\left(\mathrm{Pmin} / \mathrm{m}^{3}\right)($ Eq. 11)

$T C_{\text {MFР Тн в }}=1.20 \times\left(\frac{0.7 \mathrm{~s}}{V g} \times\left(\left(3.3229+9.8999 \times\left(\frac{V g}{0.7 \mathrm{~s}}\right)^{0.7}\right) \times\left(1+0.0021 \times e^{0.0688 \times s}\right)\right)\right)\left(\operatorname{Pmin} / \mathrm{m}^{3}\right)$

(Eq. 12)

Forwarding roundwood to roadside with a forwarder (FO)

The TC model for forwarding in FF was based on Brunberg (2004). The slope effect was based on Hartsough et al. (2001) regression for not self-leveling cabin machinery, the results from the original regression were increased by $15 \%$, as the difference found when comparing TCs from Brunberg (1995) \& Brunberg (2004) for harvesters and forwarders as function of slope. The forwarder's load size in FF was fixed to $14 \mathrm{~m}^{3}$ solid.

Parameters: $V r=$ removal volume ( $\mathrm{m}^{3}$ over bark/ha), $\mathrm{Ls}=$ load size ( $\mathrm{m}^{3}$ solid), $D f=$ extraction distance ${ }^{11}$ (m) (fixed to $300 \mathrm{~m}), \mathrm{S}=$ slope $(\%)$

$T C_{F O F F}=$

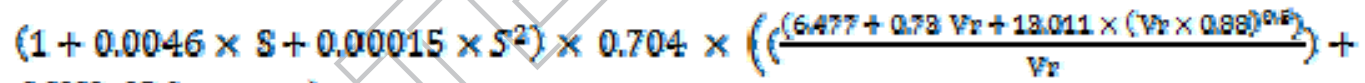
$\left.\frac{0.0202 \times 2 D F}{E g}+0.222\right)$

$\left(\mathrm{Pmin} / \mathrm{m}^{3}\right)(\mathrm{Eq} .13)$

11 The "extraction distance" is the distance from the stump to the roadside. It is set to $300 \mathrm{~m}$ for altitudes below 600 $\mathrm{m}$ and for wheeled machinery it increases for higher altitudes (classes) in the model:

If altitude $<300 \mathrm{~m} \quad$ Extraction distance is set to $\quad 300 \mathrm{~m}$

$\begin{array}{llll}\text { /1) } & 300-600 \mathrm{~m} & / / & 300 \mathrm{~m} \\ / / & 600-1100 \mathrm{~m} & / / & 500 \mathrm{~m} \\ / / & 1100-1500 \mathrm{~m} & / / & 700 \mathrm{~m} \\ / / & >2500 \mathrm{~m} & / / & 1000 \mathrm{~m}\end{array}$


In case of TH, the TC was based on Brunberg (2004) model (Eq. 13) and the TC for terminal operations was increased by $40 \%$ as the difference measured with Brunberg's (2004) models in TH and FF (i.e. considering removal volume (Vr) of $100 \mathrm{~m}^{3} / \mathrm{ha}$ and forwarding distance (Df) of $300 \mathrm{~m}$. The load size in $\mathrm{TH}$ was fixed to $10 \mathrm{~m}^{3}$ solid.

$$
\begin{aligned}
& T C_{F O T H}= \\
& \left(\left(1+0.0046 \times 5+0.00015 \times S^{2}\right) \times 0.704 \times(1.4 \times\right. \\
& \left.\left.\left(\frac{(6.477+0.78 \mathrm{Vr}+18.011 \times(\mathrm{Fr} \times 0.98005)}{\mathrm{Fr}}\right)+\frac{0.0202 \times 20 f}{4}+0.222\right)\right)
\end{aligned}
$$

$\left(\mathrm{Pmin} / \mathrm{m}^{3}\right)($ Eq. 14)

\section{$\underline{\text { Extraction of logs with a farm tractor (FT) }}$}

In case of extraction of logs with a farm tractor equipped with forest trailer, the time consumption of a forwarder (Eq, 13-14) was increased by a $15 \%$ at forwarding distance of $300 \mathrm{~m}$, the slope factors were applied as for a forwarder. For longer distances than $300 \mathrm{~m}$, the time consumption was calculated by assuming a 20\% smaller load size than a forwarder according to Spinelli et al. (2015) and a 50\% higher speed.

\section{Skidding logs with a skidder (SKL)}

The time consumption per working cycle in a final felling (FF) for a skidder was based on Borz et al. (2014) models. The number of stems per cycle in a final felling was fixed to " 3 " and the relation between stem volume and load volume per skidding cycle were calculated according to Kluender et al (1997). The slope effect for a rubber skidder was calculated from Olsen \& Gibbons (1983) relation and added to the model.

Parameters: $V s=$ stem volume $\left(\mathrm{m}^{3}\right.$ over bark), $D f=$ extraction distance $(\mathrm{m})$ (fixed to $\left.300 \mathrm{~m}\right), \mathrm{S}=$ slope $(\%)$

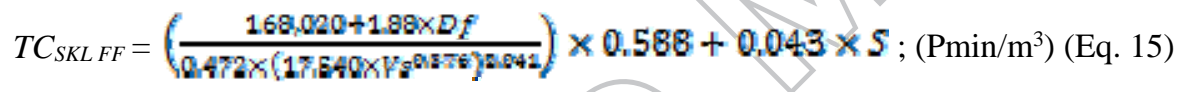

In the case of thinning (TH), the time consumption in FF was increased according to the difference noticed by Kluender et al (1997), when considering a removal of $40 \%$ in basal area, that is a $35 \%$ extra time.

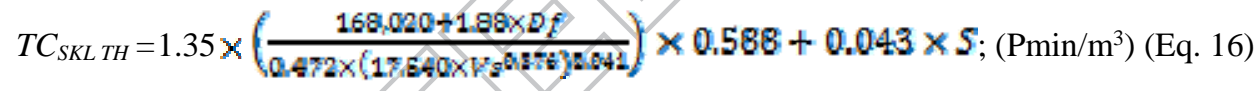

Skidding whole trees with a skidder (SKW)

In the case of skidding whole trees in a final felling, the same model as in SKL (Eq. 15) was applied and the "whole tree volume" in the model was calculated as $\frac{V_{g}}{0,7 \% 5}$.

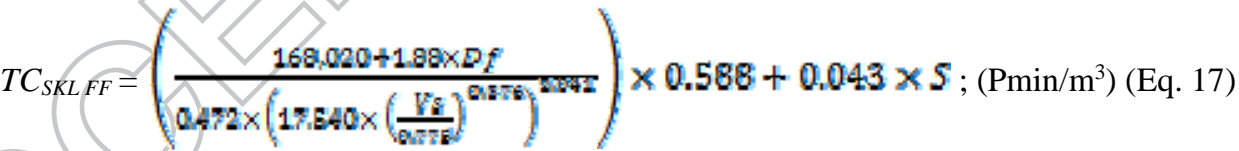

In thinning the same model as in Eq. 16 was applied and the "whole tree volume" was calculated as $\frac{W s}{0.725}$

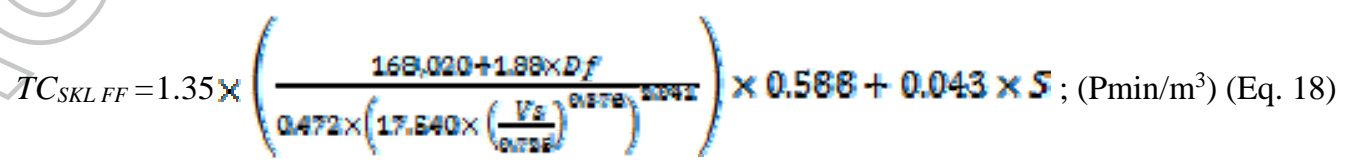

Cable yarding roundwood logs (CYL) 
The time consumption is based on Kühmaier (2013) \& Stampfer et al. (2003) models, the piece volume used in the functions was modeled from the stem volume by logarithmic relation.

Parameters: $V s=$ stem volume ( $\mathrm{m}^{3}$ over bark), $D f=$ extraction distance $(\mathrm{m})$ (fixed to $\left.300 \mathrm{~m}\right)$, S= slope $(\%)$

$\mathrm{TC}_{C Y L F F}=-0.7548+0.0122 \times \mathrm{Df}+0.7782 \times\left(\frac{V s}{(1.1818 \mathrm{~V} \times \ln (V s)+8.8196)}\right)^{-1.08}+0.0377 \times 5 ;\left(\mathrm{Pmin} / \mathrm{m}^{3}\right)$

(Eq. 19)

In thinning (TH) for logs, the TC was assumed to increase by half the time increase recorded for "Tree-Length" extraction in TH compared to FF (c.f. Stampfer et al. 2003).

$\mathrm{TC}_{C Y L T H}=0.01+0.0122 \times D f+0.7782 \times\left(\frac{v g}{(1.16158 \times \ln (v g)+5.8196)}\right)^{-1.08}+0.0377 \times 5 ;\left(\mathrm{Pmin} / \mathrm{m}^{3}\right)(\mathrm{Eq}$. 20)

\section{Cable yarding whole trees (CYW)}

The TC for extraction of whole trees with a cable yarder was based on Ghaffariyan et al. (2009) model for a "Sincrofalke" cable yarder, the average load size was fixed to $1 \mathrm{~m}^{3}$ in FF and the corridor side distance was fixed to 10 m. The "whole tree volume" in the model was calculated as $\frac{W s}{0.75 s}$.

Parameters: $V s=$ stem volume ( $\mathrm{m}^{3}$ over bark), $D f=$ extraction distance $(\mathrm{m})$ (fixed to $\left.300 \mathrm{~m}\right), \mathrm{S}=$ slope $(\%)$

$\mathrm{TC}_{C Y W F F}=2.72+0.005 \times D f+0.601 \times\left(\frac{v_{s}}{0.7 \% \mathrm{~s}}\right)^{-0.8}+0.038 \times 5 ;\left(\mathrm{Pmin} / \mathrm{m}^{3}\right)(\mathrm{Eq} .21)$

In the case of $\mathrm{TH}$, the same model as in FF was applied, by setting the thinning intensity to 30\%, the cable yarder load volume was set to $0.5 \mathrm{~m}^{3}$ and the "whole tree volume" was calculated as $\frac{W a}{0.725}$.

$\mathrm{TC}_{C Y W T H}=2.92+0.01 \times D f+1.202 \times\left(\frac{\mathrm{Fg}}{0.72 \mathrm{~s}}\right)^{-0.8}+0.076 \times S ;\left(\mathrm{Pmin} / \mathrm{m}^{3}\right)(\mathrm{Eq} .22)$

Mechanized processing at the roadside (crosscutting and delimbing) with excavator mounted processor head (PCH)

The TC for a processor mounted on excavator was calculated with the model of Hartsough et al. (2001), the model was built on conifers. Therefore, the TC was increased by $10 \%$ in the case of broadleaves. The "DBH" used in the original function was exponentially modeled as function of stem volume.

Parameters: $V s=$ stem volume ( $\mathrm{m}^{3}$ over bark)

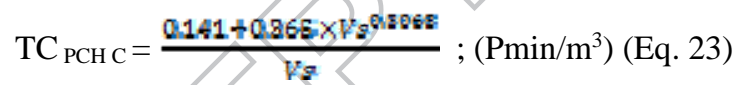

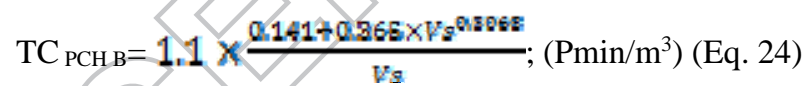

Motor-manual processing at the roadside (cross-cutting and delimbing) with chainsaw (PCM)

The time consumption was obtained as the difference of the TC for felling and processing and the TC for felling (i.e. $\mathrm{TC}_{\mathrm{PCM}}=\mathrm{TC}_{\mathrm{MFP}}-\mathrm{TC}_{\mathrm{MF}}$ ). The obtained $\mathrm{TC}$ was reduced by $10 \%$ in order to account for the easier conditions at the roadside compared to the forest terrain.

Parameters: $V s=$ stem volume $\left(\mathrm{m}^{3}\right.$ over bark)

$\mathrm{TC}_{\text {PCM C }}=4.3431 \times V_{s}-0.6 \mathrm{E2} ;\left(\mathrm{Pmin} / \mathrm{m}^{3}\right)(\mathrm{Eq} .25)$

$m$

$\mathrm{TC}_{\text {PCM в }}=6.6472 \times V_{S^{-0.575}} ;\left(\operatorname{Pmin} / \mathrm{m}^{3}\right)(\mathrm{Eq} .26)$ 


\section{Piling logging residues with a harvester $\left(H A_{L R}\right)$}

A regression for calculating the extra time needed for piling logging residues in a separate pile was based on differences found by Brunberg (2007) for final fellings and Di Fulvio \& Bergström (2013) in thinnings, compared to roundwood production. The time was assumed to be exponentially related to the stem volume:

Parameters: $V s=$ stem volume $\left(\mathrm{m}^{3}\right.$ over bark)

$T C_{H A L R}=0.0026 \times \mathrm{Vs}^{-2.084} ;\left(\mathrm{Pmin} / \mathrm{m}^{3}\right)($ Eq. 27)

\section{Motor-manual piling logging residues (MFP ${ }_{L R}$ )}

The extra time for piling logging residues in case of motor-manual felling and processing was modeled according to the differences measured by Stampfer et al. (2002) when comparing conventional roundwood production, and by assuming an exponential relation with the stem volume.

Parameters: $V s=$ stem volume ( $\mathrm{m}^{3}$ over bark)

$\mathrm{TC}_{\mathrm{MFP}} \mathrm{LR}=1,211 \times V \mathrm{~s}^{-0.800} ;\left(\mathrm{Pmin} / \mathrm{m}^{3}\right)($ Eq. 28$)$

$\underline{\text { Piling logging residues at roadside with a processor }}\left(\underline{{ }^{P C H}} \underline{L R}\right)$

The extra time needed for a processor for piling logging residues at the roadside was assumed

$\mathrm{TC}_{\mathrm{PCH} L \mathrm{LR}}=0.5\left(\mathrm{~min} / \mathrm{m}^{3}\right)$

Piling logging residues at roadside in motor-manual operation $\left(P C M_{L R}\right)$

The extra time needed in motor-manual operations for piling logging residues at the roadside was assumed

$\mathrm{TC}_{\mathrm{PCM} \mathrm{LR}}=2.0\left(\mathrm{~min} / \mathrm{m}^{3}\right)$

Forwarding logging residues with a forwarder $\left(F O_{\underline{L R}}\right)$

The TC for forwarding logging residues to roadside was based on Brunberg \& Eliasson (2011) and Nurmi (2007) model. The slope effect was assumed as in Eq. 13-14. The forwarder load size was fixed to $9.65 \mathrm{~m}^{3}$ solid:

$\mathrm{Vr}=$ removal volume $\left(\mathrm{m}^{3} / \mathrm{ha}\right), D f=$ forwarding distance $(\mathrm{m})$ (fixed to $\left.300 \mathrm{~m}\right)$, $\mathrm{S}=$ slope $(\%)$

$T C_{F O L R F F}=\left(\left(1+0.0046 \times \mathrm{s}+0.00015 \times S^{2}\right) \times\left(11.944 \times V r^{-0.524}+0.0048 \times D f^{\prime}\right)\right) ;\left(\mathrm{Pmin} / \mathrm{m}^{3}\right)$

(Eq. 29)

In $\mathrm{TH}$, the time consumption was based on Laitila et al. (2007) and Nurmi (2007), load size was fixed to $8.45 \mathrm{~m}^{3}$ solid:

$T C_{F O L R T H}=\left(\left(1+0.0046 \times \mathrm{S}+0.00015 \times S^{2}\right) \times\left(2.925 \times V r^{-0.106}+0.0048 \times D f^{\prime}\right)\right) ;\left(\mathrm{Pmin} / \mathrm{m}^{3}\right)$

(Eq. 30)

Forwarding logging residues with a farm tractor ( $F T_{\underline{L R}}$ )

According to the assumptions for extraction of roundwood, also in the case of logging residues, the time consumption was obtained by increasing of $15 \%$ the time consumption of a forwarder at $300 \mathrm{~m}$, given in eq. $29-30$, and by applying the same assumption made in case of roundwood for modeling effects of distance and slope.

Chipping logging residues $(\mathrm{CH})$ 
The TC for chipping logging residues was based on the model from Ghaffariyan et al. (2013), the machine power was set to $400 \mathrm{~kW}$, in case of a truck mounted chipper with a container discharge, and the piece size was set to 0.02 $\mathrm{m}^{3}$.

Parameters: Ps= piece size (it is fixed to $0.02 \mathrm{~m}^{3}$ )

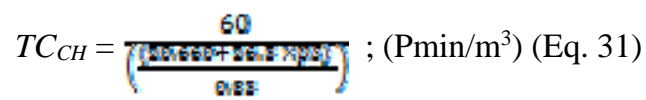

Time consumption for roundwood (WD) transportation (TR) with truck and trailer

The time consumption (TC) model for truck transportation was based on Nurminen and Heinonen (2007) as the average time for transporting pulpwood and sawlogs. The model was intended for a truck and trailer equipped with the crane (i.e. self-loading). The truck load capacity and road transportation distances are considered as variables in the model.

TC=time consumption $\left(\mathrm{min} / \mathrm{m}^{3}\right)^{12}$

Parameters:

$L c=$ load capacity of a truck and trailer unit ( $\mathrm{m}^{3}$ solid) in the country (j) given by Annex 2.

$D t=$ transportation distance $(\mathrm{km})$ from a forest stand to a conversion facility as given by a GIS calculations in a 5 $\mathrm{km}$ forest grid.

$T C_{T R W D}=1.60+\frac{2 Q 610}{2 \varepsilon}+\frac{(16,972+1656 \times D E}{(\Sigma \sigma)} ;\left(\mathrm{min} / \mathrm{m}^{3}\right)(\mathrm{Eq} .32)$

Time consumption for wood chips (WC) transportation (TR) with a container truck and trailer

A truck and trailer with 2-3 container (i.e. the number of containers was Country adjusted according to the maximum load capacity limits) was considered; no crane was considered on the truck (i.e. chips are loaded into containers from a chipper-truck during chipping operations). The loading of containers was assumed to be made from the ground with a hook equipment installed on the truck. The terminal time consumption was based on Johansson \& Liss (2006).

Factors: $L c=$ truck load capacity ( $\mathrm{m}^{3}$ solid) in the country (j) given in Annex 2.

$D t=$ transportation distance $(\mathrm{km})$ from a forest stand to a facility as given by the GIS calculations in a $5 \mathrm{~km}$ forest grid.

$T C_{T R W C}=1.76+\frac{7.990}{20}+\frac{(16972+1656 \times D \mathrm{t}}{(\mathrm{EO})} ;\left(\mathrm{min} / \mathrm{m}^{3}\right)(\mathrm{Eq} .33)$

\section{References Annex 1}

Borz S.A., Ignea G., Popa B. 2014. Assessing timber skidding efficiency in a group shelterwood system applied to a fir-beech stand. Afr J Agric Res 9(1): 160-167.

Brunberg T. 2004. Underlag till produktionsnormer för skotare. (Productivity-norm data for forwarders). Redogörelse från Skogforsk nr 3, Skogforsk The Forest Research Institute of Sweden, Uppsala.

Brunberg T. 2007. Underlag för produktionsnormer för extra stora engreppskördare i slutavverkning. (Basic data for productivity norms for extra large single-grip harvesters in final felling). Redogörelse från Skogforsk nr 2, Skogforsk The Forest Research Institute of Sweden, Uppsala.

\footnotetext{
${ }^{12}$ In the case of road transportation, the delays were included into the time consumption model as conventional prac-
} tice for this operation. 
Brunberg T., 1995. Underlag för producktionsnorm för stora engreppskördare i slutavverkning. Basic data for productivity norms for heavy-duty single-grip harvesters in final felling. Redogörelse nr. 7, Skogforsk, The Forest Research Institute of Sweden, Uppsala.

Brunberg T., Eliassson L. 2013. Productivity standards for forwarding of logging residues. In Efficient forest fuel supply systems. ESS R\&D programme 2007-2010 Skogforsk. ISBN 978-91-977649-4-0 116 p.

Di Fulvio F., Bergström D. 2013. Analyses of a single-machine system for harvesting pulpwood and/or energywood in early thinnings. Int J For Eng 24 (1): 2-15.

Eriksson M., Lindroos O. 2014. Productivity of harvesters and forwarders in CTL operations in northern Sweden based on large follow-up datasets. Int J For Eng 25(3): 179-200.

Erni V., Lemm R., Frutig F., Breitenstein M., Riechsteiner D., Oswald K., Thees O. 2003: HeProMo Produktivitätsmodelle für Holzerntearbeiten. Windows-Software, Version 1.01; Eidgenössische Forschungsanstalt WSL, Birmensdorf.

Ghaffariyan M.R., Spinelli R., Brown M. 2013. A model to predict productivity of different chipping operations. Southern Forests 75 (3): 129-136.

Ghaffariyan M.R., Spinelli R., Brown M. 2013. A model to predict productivity of different chipping operations. Southern Forests 75 (3): 129-136.

Hartsough B. R., Zhang X., Fight, R. D. 2001. Harvesting cost model for small trees in natural stands in the interior Northwest. Forest Prod J 51 (4): 54-61.

Johansson J., Liss J.E. 2006. Utvärdering av nytt ekipage för vidaretransport av bränsleflis. Högskolan Dalarna, Institutionen för matematik, naturvetenskap och teknink. Arbetsdokument nr 3. Grapenberg, 25 p.

Kluender R. Lortz D., Mc Coy W., Stokes B., Klepac J. 1997. Productivity of rubber-tired skidders in Southern pine forests. Forest Prod J 47 (11/12): 53-58.

Kühmaier, M. 2013. OEKOCHIP, Multi-criteria analysis of energy-wood supply chains. Institute of Forest Engineering, Department of Forest and Soil Sciences, University of Natural Resources and Life Sciences, Windows Software. June 2013. Vienna, Austria.

Laitila J., Asikainen A. and Nuutinen Y. 2007. Forwarding of whole trees after manual and mechanized felling bunching in pre-commercial thinnings. Int J For Eng 18(2): 29-39.

Lehtonen A., Mäkipää R., Heikkinen J., Sievänen R., Liski. J. 2004. Biomass expansion factors (BEFs) for Scots pine, Norway spruce and birch according to stand age for boreal forests. Forest Ecol Manag 188 (2004): $211-224$.

Lotz D., Kluender R., McCoy W., Stokes B., Klepac J. 1997. Manual felling time and productivity in Southern pine forests. Forest Prod J 47 (10): 59-63.

Nurmi J. 2007. Recovery of logging residues for energy from spruce (Pices abies) dominated stands. Biomass Bioenergy 31: 375-380.

Nurminen T. \& Heinonen J. 2007. Characteristics and time consumption of timber trucking in Finland. Silva Fenn 41(3): 471-487.

Nurminen T., Korpunen H. \& Uusitalo J. 2006. Time consumption analysis of the mechanized cut-to-length harvesting system. Silva Fenn 40 (2): 335-363.

Olsen E. D. \& Gibbons D. J. 1983. Predicting skidder productivity: a mobility model. Forest Research Laboratory, Oregon State University, Corvallis. Research Bulletin 43, 19 p. 
Spinelli R., Magagnotti N., Pari L., De Francesco F. 2015. A comparison of tractor-trailer units and high-speed forwarders used in Alpine forestry, Scand J For Res 30 (5): 470-477.

Spinelli R., Hartsough B.R., Magagnott, N. 2010. Productivity standards for harvesters and processors in Italy. Forest Prod J 60 (3): 226-235.

Stampfer K. 2002.: Optimierung von Holzerntesystemen im Gebirge. Habilitationsschrift eingereicht an der Universität für Bodenkultur Wien, 96 p.

Stampfer K., Limbeck-Lilienau B., Kanzian C, Viertler K. 2003: Baumverfahren im Seilgelände Verfahrensbeispiele. - Wien: Eigenverlag des FPP Kooperationsabkommens Forst-Platte-Papier, 27 p.

Annex 2. Technical utilization factors for machinery/equipment included in the selected harvesting systems.

\begin{tabular}{|c|c|c|c|c|c|}
\hline Machinery & $\begin{array}{l}\text { Sv } \\
\text { Salvage value } \\
\left(\text { ratio on } \mathrm{Pc}^{13} \text { ) }\right.\end{array}$ & $\begin{array}{l}\text { EEL } \\
\text { Economic } \\
\text { life } \\
\text { (years) }\end{array}$ & $\begin{array}{l}\text { SMH } \\
\text { Annual } \\
\text { utilization } \\
\text { (SMH/year) }\end{array}$ & $\begin{array}{l}\text { U } \\
\text { Utili } \\
\text { rate } \\
\text { (PMl }\end{array}$ & Reference $^{15}$ \\
\hline Harvester & 0.2 & 7.2 & 2500 & & $\begin{array}{l}\text { Eriksson \& } \\
\text { Lindroos } \\
2014\end{array}$ \\
\hline Chainsaw & 0.1 & 2.1 & 1680 & 0.50 & Miyata 1980 \\
\hline Forwarder & 0.2 & 6.3 & & 0.84 & $\begin{array}{l}\text { Eriksson \& } \\
\text { Lindroos } \\
2014\end{array}$ \\
\hline Farm Tractor & 0.2 & & 30 & 0.65 & Miyata 1980 \\
\hline
\end{tabular}

Eriksson, M., Lindroos, O. 2014. Productivity of harvesters and forwarders in CTL operations in northern Sweden based on large follow-up datasets. Int J For Eng 25(3): 179-200.

Miyata, E. S., 1980. Determining fixed and operating costs of logging equipment. General Technical Report GTRNC-55. USDA Forest Service, North Central Forest Experiment Station. St. Paul, MN. 20 p.

Holzleitner, F., Stampfer, K., Visser, R. 2011. Utilization rates and cost factors in timber harvesting based on Longterm Machine Data. Cro J For Res 32 (2): 501-508.

Brinker, R., W., Kinard, J., Rummer, B., Landford, B. 2002. Machine rates for selected forest harvesting machines. Circular 296, September 2002. Alabama Agricultural Experiment Station. Auburn University, Auburn, Alabama. 32 p. 


\begin{tabular}{lccccl}
\hline Skidder & 0.2 & 8.5 & 1680 & 0.70 & $\begin{array}{l}\text { Holzleitner et } \\
\text { al. 2011 }\end{array}$ \\
Cable yarder & 0.2 & 8.1 & 1680 & 0.66 & $\begin{array}{l}\text { Holzleitner et } \\
\text { al. 2011 }\end{array}$ \\
Chipper & 0.2 & 6.0 & 2000 & 0.75 & $\begin{array}{l}\text { Brinker et al. } \\
2002\end{array}$ \\
$\begin{array}{l}\text { Processor on } \\
\text { excavator }\end{array}$ & 0.2 & 8.0 & 1680 & 0.67 & Miyata 1980 \\
\hline
\end{tabular}


Annex 3. Machinery costs parameters collected in the Reference countries (Sweden=SWE, Austria $=A T$ ) for most relevant systems in the $E U$.

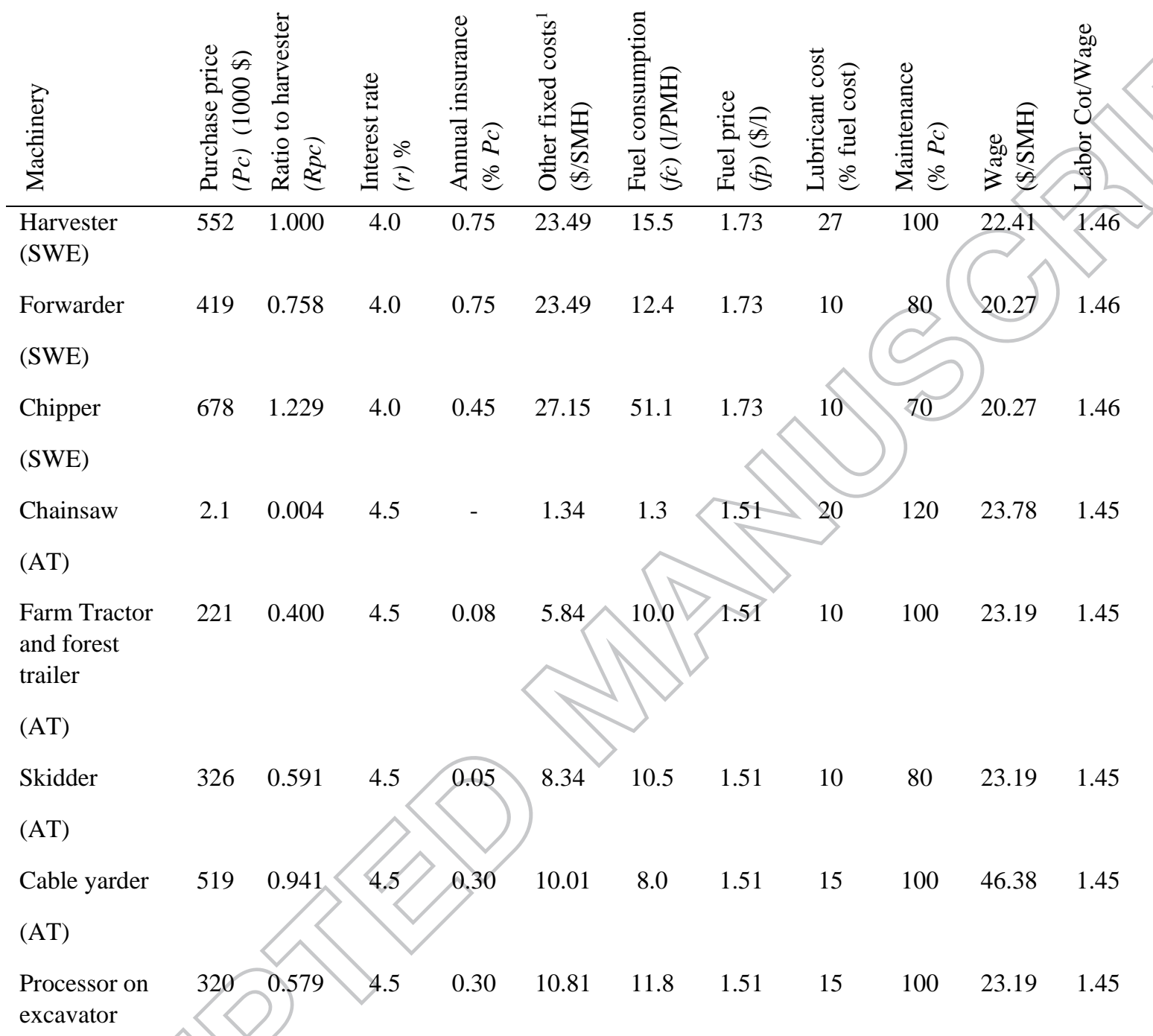

(AT)

${ }^{1}$ It includes machinery taxes \& garaging and general costs for operators (training, transportation, phone charges, and protective equipment), it is a cost assumed to be independent from country's borders. ${ }^{2}$ SLU (Sweden) and BWF/AUSTROFOMA (Austria).

Annex 4. Cost benchmarking database for felling operations used for adaptation of unitary costs to country borders.

\begin{tabular}{|l|l|}
\hline Country/Region & Expert \& Institution \\
\hline Australia & $\begin{array}{l}\text { Mauricio Acuna, Mohammad Ghaffariyan, } \\
\text { AFORA }\end{array}$ \\
\hline
\end{tabular}




\begin{tabular}{|c|c|}
\hline Brazil & $\begin{array}{l}\text { Saulo Guerra, Guilherme Oguri, } \\
\text { UNESP }\end{array}$ \\
\hline Canada & $\begin{array}{l}\text { Luc LeBel, Shuva Hari Gautam, Pierre-Serge Tremblay, } \\
\text { Univerity of Laval }\end{array}$ \\
\hline France & $\begin{array}{l}\text { Paul Magaud, Philippe Ruch, } \\
\text { FCBA }\end{array}$ \\
\hline Germany & $\begin{array}{l}\text { Jörg Hittenbeck, } \\
\text { University of Göttingen }\end{array}$ \\
\hline Italy & $\begin{array}{l}\text { Raffaele Spinelli, Natascia Magagnotti, } \\
\text { CNR-IVALSA }\end{array}$ \\
\hline Japan & $\begin{array}{l}\text { Kazuhiro Aruga, } \\
\text { Utsunomiya University }\end{array}$ \\
\hline Latvia & $\begin{array}{l}\text { Andis Lazdiņš, } \\
\text { SILAVA }\end{array}$ \\
\hline Norway & $\begin{array}{l}\text { Bruce Talbot, } \\
\text { Skogoglandskap Institute }\end{array}$ \\
\hline Portugal & $\begin{array}{l}\text { Helder Viana, } \\
\text { Polytechnic Institute of Viseu Portu }\end{array}$ \\
\hline Slovenia & $\begin{array}{l}\text { Nike Krajnc, } \\
\text { SFI }\end{array}$ \\
\hline South Africa & $\begin{array}{l}\text { Pierre Ackerman, Simon Ackerman, } \\
\text { Stellenbosch University }\end{array}$ \\
\hline Spain & $\begin{array}{l}\text { Sandra Sanchez, Elena Canga, } \\
\text { CETEMAS }\end{array}$ \\
\hline Sweden North & $\begin{array}{l}\text { Ola Lindroos, } \\
\text { SLU }\end{array}$ \\
\hline Sweden & $\begin{array}{l}\text { Lars Eliasson, } \\
\text { Skogforsk }\end{array}$ \\
\hline US Maine & $\begin{array}{l}\text { Steve Bick, Northeast Forests, } \\
\text { LLC }\end{array}$ \\
\hline $\begin{array}{l}\text { US Michigan, US Minnesota, } \\
\text { US Tennessee }\end{array}$ & $\begin{array}{l}\text { Dalia Abbas, } \\
\text { Uniyersity of Georgia }\end{array}$ \\
\hline US North-West & $\begin{array}{l}\text { Beth Dodson, } \\
\text { University of Montana }\end{array}$ \\
\hline US West Virginia & $\begin{array}{l}\text { Jingxin Wang, } \\
\text { West Virginia University }\end{array}$ \\
\hline
\end{tabular}

\section{Annex 5. Collection of factors used in the country border adaptation of time unit costs.}

\begin{tabular}{|c|c|c|c|c|c|c|c|c|}
\hline ن & 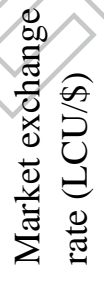 & 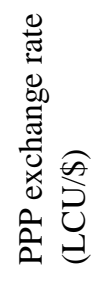 & 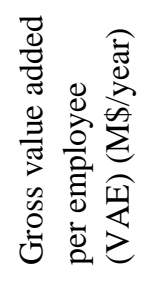 & 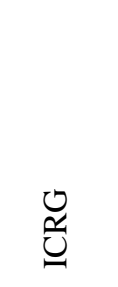 & 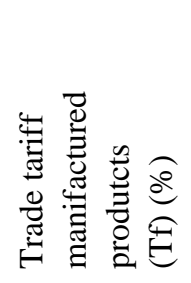 & 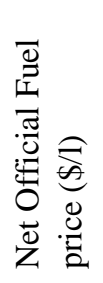 & 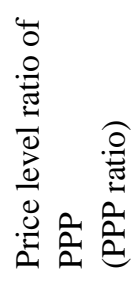 & $\begin{array}{l}0 \\
0 \\
0 \\
3 \\
5 \\
0 \\
0 \\
0 \\
0 \\
0 \\
0\end{array}$ \\
\hline Austria & 0.875 & 0.980 & 52 & 81.000 & 1.554 & 1.508 & 1.120 & 1.454 \\
\hline Belgium & 0.875 & 0.987 & 53 & 75.500 & 1.554 & 1.636 & 1.129 & 1.786 \\
\hline Bulgaria & 1.457 & 0.694 & 8 & 66.750 & 1.554 & 1.400 & 0.477 & 1.222 \\
\hline Croatia & 5.536 & 3.769 & 33 & 64.250 & 2.128 & 1.360 & 0.637 & 1.179 \\
\hline Cyprus & 0.875 & 0.782 & 1 & 66.125 & 1.554 & 1.508 & 0.895 & 1.143 \\
\hline
\end{tabular}




\begin{tabular}{lcccccccc}
\hline Czech Re- & 19.001 & 13.615 & 54 & 73.000 & 1.554 & 1.545 & 0.684 & 1.515 \\
public & 5.552 & 7.580 & 76 & 80.875 & 1.554 & 1.512 & 1.366 & 1.033 \\
Denmark & 0.875 & 0.639 & 52 & 71.000 & 1.554 & 1.467 & 0.731 & 1.515 \\
Estonia & 0.875 & 1.082 & 161 & 79.625 & 1.554 & 1.573 & 1.237 & 1.282 \\
Finland & 0.875 & 0.992 & 121 & 73.500 & 1.554 & 1.488 & 1.134 & 1.736 \\
France & 0.875 & 0.922 & 63 & 81.250 & 1.554 & 1.580 & 1.054 & 1.246 \\
Germany & 0.875 & 0.748 & 18 & 65.875 & 1.554 & 1.691 & 0.856 & 1.379 \\
Greece & 212.028 & 126.610 & 15 & 68.750 & 1.554 & 1.504 & 0.578 & 1.504 \\
Hungary & 0.875 & 0.966 & 73 & 74.500 & 1.554 & 1.610 & 1.105 & 1.120 \\
Ireland & 0.875 & 0.885 & 30 & 71.750 & 1.554 & 1.787 & 1.011 & 1.555 \\
Italy & 0.875 & 0.595 & 51 & 65.875 & 1.554 & 1.463 & 0.682 & 1.316 \\
Latvia & 2.572 & 1.586 & 28 & 70.750 & 1.554 & 1.405 & 0.610 & 1.453 \\
Lithuania & 0.875 & 1.063 & 170 & 83.875 & 1.554 & 1.426 & 1.215 & 1.149 \\
Luxem- & & & & & & & \\
bourg & 0.875 & 0.869 & 0 & 73.125 & 1.554 & 1.483 & 0.782 & 1.111 \\
Malta & 0.875 & 0.962 & 40 & 78.750 & 1.554 & 1.612 & 1.100 & 1.210 \\
Netherlands & 3.103 & 1.788 & 38 & 73.000 & 1.554 & 1.407 & 0.576 & 1.389 \\
Poland & 0.875 & 0.684 & 95 & 72.125 & 1.554 & 1.537 & 0.782 & 1.311 \\
Portugal & 3.214 & 1.609 & 42 & 66.125 & 1.554 & 1.395 & 0.500 & 1.389 \\
Romania & 0.875 & 0.596 & 29 & 73.125 & 1.554 & 1.542 & 0.681 & 1.543 \\
Slovakia & 0.875 & 0.706 & 24 & 69.000 & 1.554 & 1.451 & 0.807 & 1.192 \\
Slovenia & 0.875 & 0.790 & 47 & 70.625 & 1.554 & 1.446 & 0.903 & 1.447 \\
Spain & 6.929 & 8.879 & 179 & 83.250 & 1.554 & 1.728 & 1.352 & 1.458 \\
Sweden & 0.637 & 0.688 & 27 & 75.250 & 1.554 & 1.892 & 1.092 & 1.160 \\
UK & & & & & & & &
\end{tabular}

Annex 6. Number of pulpmills, biomass power plants $(>0.2 \mathrm{MW})$, the applied density of facilities (average of column pulpmill and power plant) and the corresponding size of selected cities.

\begin{tabular}{lrrrr}
\hline Country & Pulpmill & $\begin{array}{r}\text { Power Plant } \\
\text { (n) }\end{array}$ & $\begin{array}{r}\text { Applied density of facilities } \\
\text { (n) }\end{array}$ & $\begin{array}{r}\text { City size } \\
\text { (population 1 000) }\end{array}$ \\
\hline Austria & 28 & 33 & 31 & 15 \\
Belgium & 14 & 6 & 10 & 90 \\
Bulgaria & 9 & 1 & 5 & 150 \\
Croatia & 3 & 0 & 2 & 150 \\
Cyprus & 0 & 0 & 1 & 70 \\
Czech Republic & 26 & 9 & 18 & 54 \\
Denmark & 4 & 8 & 6 & 55 \\
Estonia & 4 & 1 & 3 & 60 \\
Finland & 51 & 7 & 29 & 31 \\
France & 129 & 24 & 77 & 99 \\
Germany & 192 & 87 & 140 & 62 \\
Greece & 16 & 0 & 8 & 95 \\
\hline
\end{tabular}




\begin{tabular}{lrrrr}
\hline Hungary & 11 & 5 & 8 & 105 \\
Ireland & 0 & 2 & 1 & 130 \\
Italy & 214 & 17 & 116 & 53 \\
Latvia & 1 & 1 & 1 & 120 \\
Lithuania & 4 & 0 & 2 & 200 \\
Luxembourg & 0 & 0 & 1 & 30 \\
Malta & 0 & 0 & 1 & 20 \\
Netherlands & 23 & 11 & 17 & 124 \\
Poland & 45 & 0 & 23 & 155 \\
Portugal & 31 & 11 & 21 & 46 \\
Romania & 14 & 1 & 8 & 250 \\
Slovakia & 8 & 0 & 4 & 87 \\
Slovenia & 8 & 0 & 4 & 30 \\
Spain & 92 & 11 & 52 & 113 \\
Sweden & 57 & 40 & 49 & 22 \\
United Kingdom & 63 & 38 & 51 & 122 \\
\hline
\end{tabular}

Annex 7. Map of selected cities as a proxy of woody biomass conversion facilities.

\section{- cities_selected}

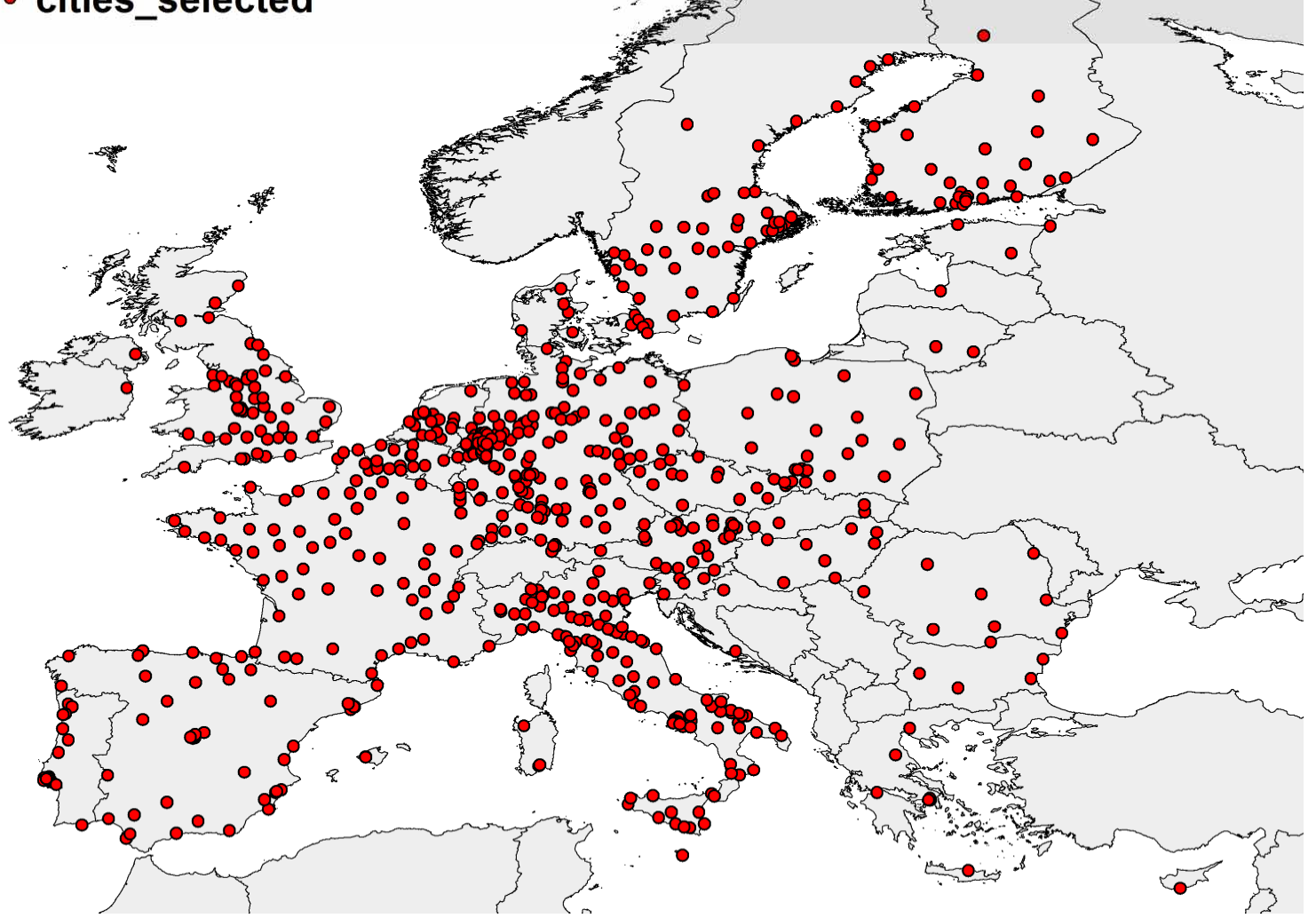


Annex 8: Adaptation of transportation costs across the country borders.

The truck and trailer fixed costs $(C f)$ in a country $(j)$ is given by the sum of interests and the other fixed costs (cfa) as:

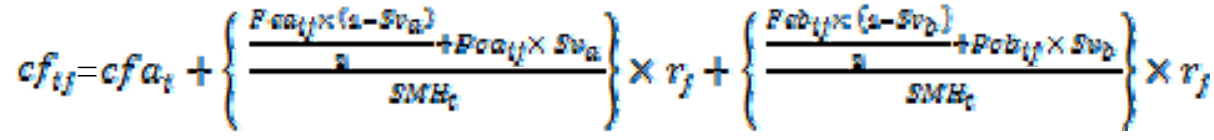

(i=operation; $j=$ country) $(\$ / \mathrm{SMH}) \quad$ (Eq. 1$)$

$P C_{a}=$ Purchase price for the truck used in operation (i) in Country (j);

${ }^{P} c_{b}=$ Purchase price for the trailer used in operation (i) in Country (j);

$S v_{a}=$ Salvage value as percentage of purchase price for truck $=0.1$;

$S v_{b}=$ Salvage value as percentage of purchase price for trailer $=0.07$

$\mathrm{SMH}_{\mathrm{t}}=$ Annual utilization of truck and trailer = $3500 \mathrm{SMH}$;

The kilometric depreciation ( $c v k)$ for a truck and trailer in the country (j) is given by:

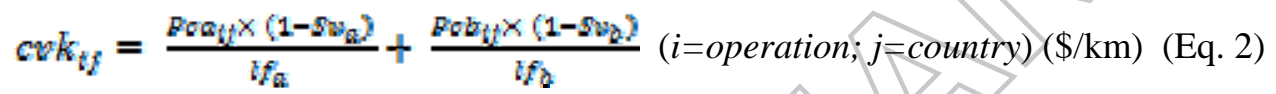

$l f_{a}=$ truck life length in $\mathrm{km}=1000000 \mathrm{~km}$;

$\iota f_{b}=$ trailer life length in $\mathrm{km}=1500000 \mathrm{~km}$;

The depreciation for crane $(c c)$ is calculated according to:

$\mathrm{CC}_{\mathrm{j}}=\frac{\overline{\theta 00} \mathrm{t} \times\left(1-S v_{\mathrm{Q}}\right)}{i f_{\mathrm{s}}} \quad$ (\$/load) (Eq. 3);

$P C c_{\gamma}=$ Purchase price for the crane in Country (j);

$S v_{e}=$ Salvage value as percentage of purchase price for crane $=0.07$

$l f_{o}=$ crane life length in number of loads $=5000$ loads

The total cost for road transportation in a generic country ( $j$ ) is given by:

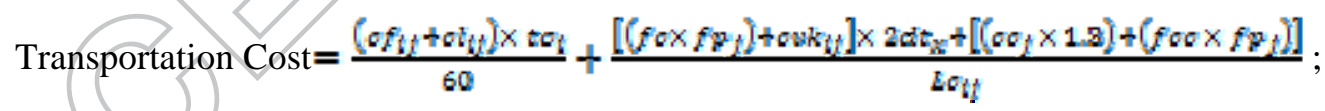

( $i=$ operation $(W D / C H) ; j=$ country; $x=$ harvesting unit $)\left(\$ / \mathrm{m}^{3}\right)($ Eq. 4$)$

$t c_{i}=$ time consumption for operation (i), given in Annex 1.

$c f_{i f}=$ fixed hourly cost for operation (i) in the Country (j), given by Eq. 1.

$c l_{i}=$ total labor hourly cost for operation (i) in the country (j) (sum of wage and social charges).

$f c_{t}=$ fuel consumption for driving in operation (i), given in Annex 10.

$f c c=$ fuel consumption for crane work given in Annex 10. 
$f p_{f}=$ fuel price in the Country (j).

$c v k_{i f}=$ Kilometric depreciation for truck and trailer for operation (i) in the Country (j), given by Eq. 2.

$L c_{i j}=$ load capacity ( $\mathrm{m}^{3}$ solid) for truck and trailers in operation (i) in each country (j) given by Annex 9.

$d t_{x}=$ transportation distance $(\mathrm{km})$ from forest roads to conversion facilities, explicitly calculated as the shortest route from the center of each SimU to the closest conversion facility in each country.

Annex 9. Load capacities $(L c)$ for a truck and trailer calculated in the EU Countries, according to the Country limitations and the products (payload limitation sourced from EU (2014) ${ }^{16}$.

\begin{tabular}{|c|c|c|}
\hline Country & $\begin{array}{r}\text { WD } \\
\text { Roundwood } \\
\left(\mathrm{m}^{3} \text { solid }\right)^{17}\end{array}$ & $\begin{array}{r}\text { WC } \\
\text { Woodchips } \\
\left(\mathrm{m}^{3} \text { solid }\right)^{18}\end{array}$ \\
\hline Austria & 26 & 19 \\
\hline Belgium & 31 & 24 \\
\hline Bulgaria & 26 & 19 \\
\hline Croatia & 26 & 19 \\
\hline Cyprus & 26 & 19 \\
\hline Czech Republic & 31 & 24 \\
\hline Denmark & 33 & 28 \\
\hline Estonia & 26 & 19 \\
\hline Finland & 45 & 32 \\
\hline France & 26 & 19 \\
\hline Germany & 26 & 19 \\
\hline Greece & 26 & 19 \\
\hline Hungary & 26 & \\
\hline Ireland & 31 & 24 \\
\hline Italy & & \\
\hline Latvia & & \\
\hline Lithuania & & \\
\hline Luxembourg & & 24 \\
\hline Malta & & 19 \\
\hline Netherlands & 35 & 31 \\
\hline Poland & 26 & 19 \\
\hline Portugal & 26 & 19 \\
\hline Romania & 26 & 19 \\
\hline Slovakia & 26 & 19 \\
\hline Slovenia & 26 & 19 \\
\hline
\end{tabular}

${ }^{16}$ European Commission 2014. EU transport in figures. Statistical Pocketbook 2014. Publications Office of the European Union, 2014. http://ec.europa.eu/transport/facts-fundings/statistics/index_en.htm

${ }_{17}^{17}$ Density of roundwood $=850$ fresh $\mathrm{kg} \mathrm{m}^{-3}$

${ }^{18}$ Density of woodchips $=900$ fresh $\mathrm{kg} \mathrm{m}^{-3}$ 


\begin{tabular}{lll}
\hline Spain & 26 & 19 \\
Sweden & 45 & 32 \\
United Kingdom & 31 & 24 \\
\hline
\end{tabular}

Annex 10. Cost parameters for truck transportation in the Reference country (Ref)

(Reference Sweden, SLU).

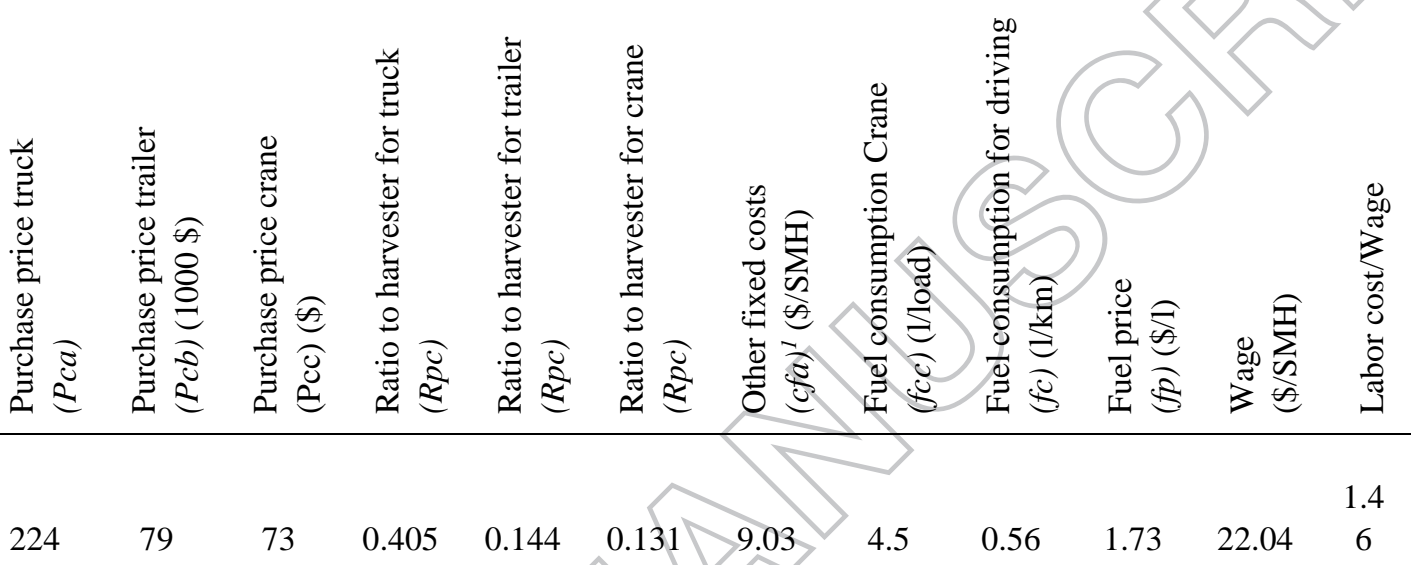

Container

truck and

trailer

wood-

chips

$224 \quad 137$

0.405

0.248

9.03

0.56

1.4

${ }^{1}$ It includes machinery taxes \& garaging and other general cost 
Annex 11. Values used for adaptation of future labor costs and fuel prices in 2030 in the "Economic growth and Forest Intensification" sensitivity analysis.

\begin{tabular}{|c|c|c|c|}
\hline Country Name & $\begin{array}{r}\text { Increase } \\
\text { of GDP } \\
\text { per capita } \\
(\%)\end{array}$ & $\begin{array}{r}\text { Price level } \\
\text { ratio of PPP } \\
\text { (PPP ratio) }\end{array}$ & $\begin{array}{r}\text { Net Official } \\
\text { Fuel price } \\
(\$ / 1)\end{array}$ \\
\hline Austria & 18 & 1.323 & 1.609 \\
\hline Belgium & 14 & 1.291 & 1.741 \\
\hline Bulgaria & 40 & 0.669 & 1.494 \\
\hline Croatia & 29 & 0.825 & 1.449 \\
\hline Cyprus & 14 & 1.018 & 1.602 \\
\hline Czech Republic & 31 & 0.895 & 1.648 \\
\hline Denmark & 19 & 1.625 & 1.605 \\
\hline Estonia & 45 & 1.060 & 1.566 \\
\hline Finland & 18 & 1.462 & 1.676 \\
\hline France & 22 & 1.388 & 1.584 \\
\hline Germany & 17 & 1.228 & 1.686 \\
\hline Greece & 19 & 1.017 & 1.797 \\
\hline Hungary & 29 & 0.743 & 1.599 \\
\hline Ireland & 34 & 1.481 & 1.705 \\
\hline Italy & 17 & 1.186 & 1.896 \\
\hline Latvia & 53 & 1.043 & 1.554 \\
\hline Lithuania & 38 & 0.840 & 1.499 \\
\hline Luxembourg & 14 & 1.389 & 1.520 \\
\hline Malta & & 1.011 & 1.578 \\
\hline Netherlands & & 1.278 & 1.717 \\
\hline Poland & & 0.796 & 1.499 \\
\hline Portugal & 27 & 0.991 & 1.633 \\
\hline Romania & 32 & 0.663 & 1.488 \\
\hline Slovakia & 40 & 0.957 & 1.637 \\
\hline Slovenia & 25 & 1.007 & 1.549 \\
\hline Spain & 33 & 1.200 & 1.544 \\
\hline Sweden & 20 & 1.616 & 1.837 \\
\hline UK & 22 & 1.330 & 2.021 \\
\hline
\end{tabular}

Annex 12. Descriptive statistics of the cost supply curves in the sensitivity analyses

\section{$\underline{\text { Standardized transportation }}$}

Roundwood 


\begin{tabular}{|c|c|c|c|c|c|}
\hline & 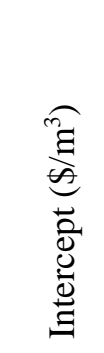 & 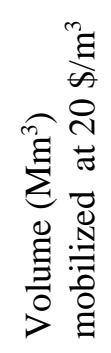 & 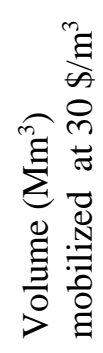 & 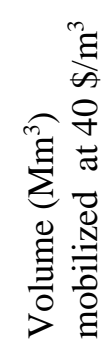 & 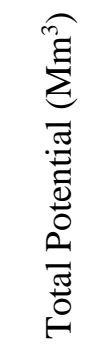 \\
\hline Austria & 20.98 & 0.0 & 7.6 & 12.3 & 20.0 \\
\hline Belgium & 21.57 & 0.0 & 4.7 & 5.8 & 5.8 \\
\hline Bulgaria & 17.38 & 2.6 & 5.1 & 5.6 & 6.3 \\
\hline Croatia & 17.24 & 3.4 & 5.7 & 6.0 & 6.2 \\
\hline Cyprus & 25.40 & 0.0 & 0.0 & 0.0 & 0.0 \\
\hline Czech & 17.28 & 13.2 & 20.2 & 20.2 & 20.3 \\
\hline Denmark & 18.88 & 1.1 & 2.9 & 3.1 & 3.1 \\
\hline Estonia & 19.63 & 0.9 & 9.8 & 10.3 & 10.7 \\
\hline Finland & 22.62 & 0.1 & 43.7 & 59.2 & 75.3 \\
\hline France & 23.79 & 0.0 & 46.7 & 84.6 & 98.4 \\
\hline Germany & 20.19 & 0.3 & 81.7 & 84.5 & 84.9 \\
\hline Greece & 28.73 & 0.0 & 0.2 & 0.4 & 1.6 \\
\hline Hungary & 19.05 & 1.3 & 7.3 & 7.8 & 7.9 \\
\hline Ireland & 18.71 & 0.7 & 3.0 & 3.2 & 3.4 \\
\hline Italy & 23.54 & 0.0 & 4.0 & 7.0 & 14.1 \\
\hline Latvia & 19.38 & 1.6 & 12.3 & 12.3 & 12.4 \\
\hline Lithuania & 18.29 & 0.9 & 6.0 & 6.7 & 6.9 \\
\hline Netherlands & 18.43 & 0.7 & 1.0 & 1.1 & 1.1 \\
\hline Poland & 17.30 & 26.8 & & 40.2 & 40.3 \\
\hline Portugal & 23.39 & 0.0 & & 10.7 & 12.3 \\
\hline Romania & 16.87 & 4.1 & 13.1 & 16.5 & 16.6 \\
\hline Slovakia & 19.00 & 0.3 & 5.4 & 7.7 & 7.7 \\
\hline Slovenia & 19.26 & $0.1>$ & 2.8 & 2.9 & 3.0 \\
\hline Spain & 24.26 & 0.1 & 4.7 & 9.4 & 22.5 \\
\hline Swede & & 0.0 & 55.1 & 84.1 & 89.4 \\
\hline UK & 19.62 & 0.1 & 10.6 & 13.0 & 14.2 \\
\hline
\end{tabular}

Logging residues 


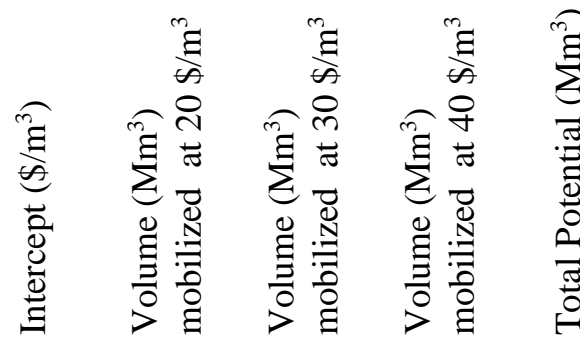

\begin{tabular}{lccccc}
\hline Austria & 26.10 & 0.0 & 0.9 & 1.9 & 2.0 \\
Belgium & 26.16 & 0.0 & 0.0 & 0.5 & 0.5 \\
Bulgaria & 21.76 & 0.0 & 0.8 & 0.9 & 0.9 \\
Croatia & 22.56 & 0.0 & 0.6 & 0.9 & 0.9 \\
Cyprus & 23.89 & 0.0 & 0.0 & 0.0 & 0.0 \\
Czech & 22.80 & 0.0 & 0.1 & 2.1 & 2.1 \\
Denmark & 29.56 & 0.0 & 0.1 & 0.4 & 0.4 \\
Estonia & 30.28 & 0.0 & 0.1 & 1.9 & 2.0 \\
Finland & 32.06 & 0.0 & 0.1 & 13.4 & 13.6 \\
France & 25.60 & 0.0 & 0.8 & 7.0 & 10.9 \\
Germany & 25.74 & 0.0 & 2.3 & 8.1 & 8.1 \\
Greece & 26.01 & 0.0 & 0.1 & 0.2 & 0.2 \\
Hungary & 23.48 & 0.0 & 0.7 & 1.4 & 1.4 \\
Ireland & 24.03 & 0.0 & 0.0 & 0.4 & 0.5 \\
Italy & 25.65 & 0.0 & 0.7 & 1.8 & 1.8 \\
Latvia & 30.07 & 0.0 & 0.1 & 1.8 & 1.8 \\
Lithuania & 28.37 & 0.0 & 0.9 & 1.4 & 1.5 \\
Netherlands & 31.43 & 0.0 & 0.0 & 0.1 & 0.1 \\
Poland & 22.74 & 0.0 & 0.2 & 3.4 & 3.4 \\
Portugal & 25.32 & 0.0 & 0.2 & 1.7 & 1.8 \\
Romania & 22.65 & 0.0 & 0.7 & 1.3 & 1.3 \\
Slovakia & 24.40 & 0.0 & 0.2 & 0.7 & 0.7 \\
Slovenia & 23.53 & 0.0 & 0.1 & 0.3 & 0.3 \\
Spain & 24.91 & 0.0 & 1.3 & 3.7 & 4.1 \\
Sweden & 25.76 & 0.0 & 0.1 & 15.7 & 15.8. \\
UK & 25.27 & 0.0 & 0.1 & 2.4 & 2.4 \\
\hline
\end{tabular}

\section{Economic Growth}

Roundwood 


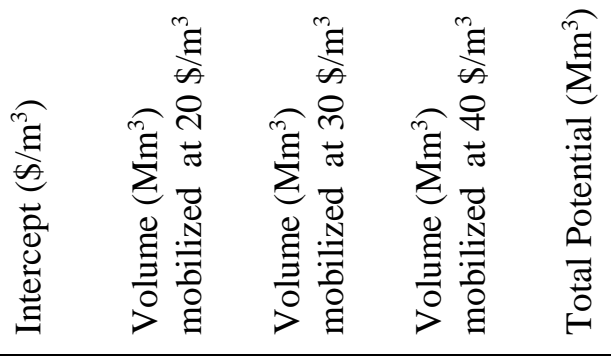

\begin{tabular}{|c|c|c|c|c|c|}
\hline Austria & 16.16 & 1.5 & 7.6 & 11.6 & 20.0 \\
\hline Belgium & 18.93 & 0.2 & 4.6 & 5.7 & 5.8 \\
\hline Bulgaria & 16.13 & 0.9 & 3.3 & 4.7 & 6.3 \\
\hline Croatia & 16.23 & 0.9 & 3.1 & 5.0 & 6.2 \\
\hline Cyprus & 25.89 & 0.0 & 0.0 & 0.0 & 0.0 \\
\hline Czech & 14.50 & 11.5 & 19.8 & 20.2 & 20.3 \\
\hline Denmark & 17.95 & 0.7 & 2.6 & 3.1 & 3.1 \\
\hline Estonia & 18.99 & 0.3 & 4.6 & 9.1 & 10.7 \\
\hline Finland & 21.09 & 0.0 & 25.9 & 52.3 & 75.3 \\
\hline France & 19.33 & 0.1 & 29.2 & 73.4 & 98.4 \\
\hline Germany & 15.10 & 25.1 & 78.0 & 84.0 & 84.9 \\
\hline Greece & 28.77 & 0.0 & 0.1 & 0.3 & \\
\hline Hungary & 16.53 & 0.6 & 4.7 & 7. & \\
\hline Ireland & 18.08 & 0.2 & 0.8 & & 3.4 \\
\hline Italy & 20.98 & 0.0 & 3.9 & & 14.1 \\
\hline Latvia & 24.32 & 0.0 & & 7.3 & 12.4 \\
\hline Lithuania & 17.51 & 0.5 & & 5.5 & 6.9 \\
\hline Netherlands & 16.50 & & & 1.1 & 1.1 \\
\hline Poland & 13.86 & & & 39.6 & 40.3 \\
\hline Portugal & 21.20 & & & 9.8 & 12.3 \\
\hline Romania & 18.37 & 4 & 4.8 & 11.0 & 16.6 \\
\hline Slovakia & & 0.9 & 3.5 & 5.2 & 7.7 \\
\hline Slovenia & & 0.2 & 2.4 & 2.8 & 3.0 \\
\hline Spain & 18.02 & 0.1 & 1.8 & 6.4 & 22.5 \\
\hline Suredo & & 0.9 & 40.4 & 76.3 & 89.4 \\
\hline & 13.48 & 3.1 & 9.0 & 11.3 & 14.2 \\
\hline
\end{tabular}

Logging residues 


\begin{tabular}{|c|c|c|c|c|c|}
\hline & 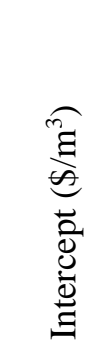 & 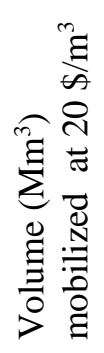 & 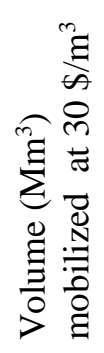 & 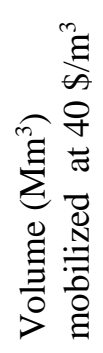 & 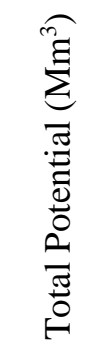 \\
\hline Austria & 18.91 & 0.0 & 0.9 & 1.8 & 2.0 \\
\hline Belgium & 26.96 & 0.0 & 0.0 & 0.5 & 0.5 \\
\hline Bulgaria & 22.58 & 0.0 & 0.2 & 0.7 & 0.9 \\
\hline Croatia & 17.14 & 0.0 & 0.2 & 0.5 & 0.9 \\
\hline Cyprus & 19.16 & 0.0 & 0.0 & 0.0 & 0.0 \\
\hline Czech & 17.87 & 0.0 & 0.7 & 2.1 & 2.1 \\
\hline Denmark & 27.75 & 0.0 & 0.1 & 0.4 & 0.4 \\
\hline Estonia & 27.36 & 0.0 & 0.0 & 0.8 & 2.0 \\
\hline Finland & 29.97 & 0.0 & 0.0 & 8.3 & 13.6 \\
\hline France & 19.45 & 0.0 & 0.2 & 4.7 & 10.9 \\
\hline Germany & 19.68 & 0.0 & 1.7 & 7.5 & 8.1 \\
\hline Greece & 24.23 & 0.0 & 0.0 & 0.1 & 0.2 \\
\hline Hungary & 23.39 & 0.0 & 0.3 & 1.0 & 1.4 \\
\hline Ireland & 24.67 & 0.0 & 0.0 & 0.2 & 0.5 \\
\hline Italy & 19.33 & 0.0 & 0.5 & & 1.8 \\
\hline Latvia & 33.30 & 0.0 & 0.0 & 0.3 & 1.8 \\
\hline Lithuania & 25.10 & 0.0 & 0.2 & 0.8 & 1.5 \\
\hline Netherlands & 28.73 & 0.0 & 0.1 & 0.1 & 0.1 \\
\hline Poland & 20.24 & 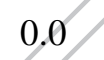 & 05 & 2.1 & 3.4 \\
\hline Portugal & 18.93 & & 0.2 & 1.2 & 1.8 \\
\hline Romania & 21.07 & . & 0.1 & 0.6 & 1.3 \\
\hline Slovakia & 23.96 & 0.0 & 0.1 & 0.3 & 0.7 \\
\hline Slovenia & 23.37 & 0.0 & 0.0 & 0.3 & 0.3 \\
\hline Spain & 21.17 & 0.0 & 0.5 & 1.8 & 4.1 \\
\hline Swed & 29.79 & 0.0 & 0.0 & 8.6 & 15.8 \\
\hline UK & 21.88 & 0.0 & 0.3 & 1.7 & 2.4 \\
\hline
\end{tabular}

\section{Forestry Intensification}

Roundwood 


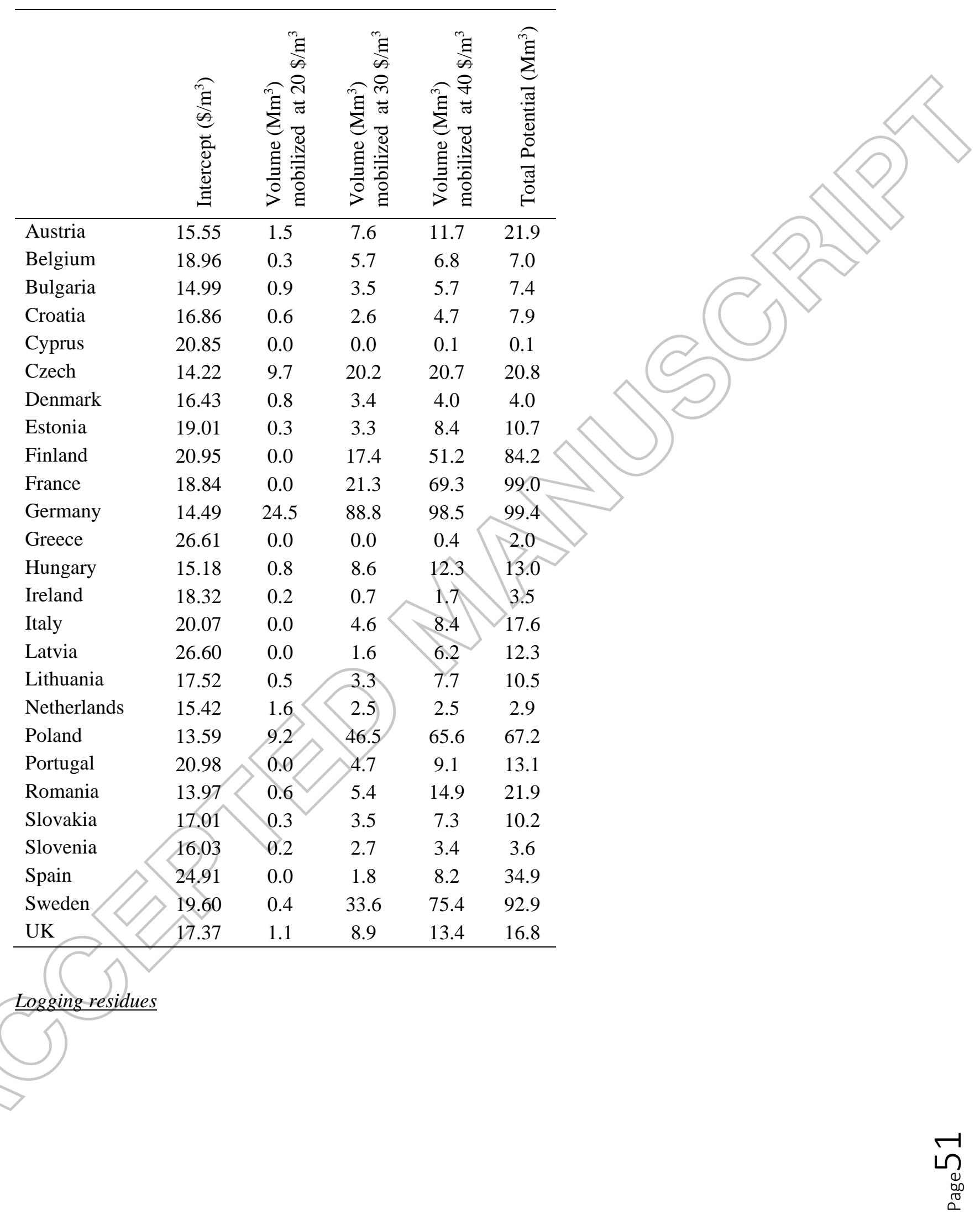




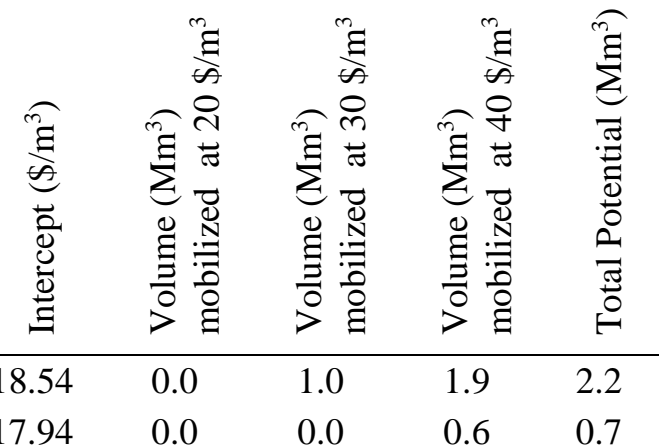

\begin{tabular}{lcllll}
\hline Austria & 18.54 & 0.0 & 1.0 & 1.9 & 2.2 \\
Belgium & 17.94 & 0.0 & 0.0 & 0.6 & 0.7 \\
Bulgaria & 17.69 & 0.0 & 0.3 & 0.8 & 1.0 \\
Croatia & 17.15 & 0.0 & 0.1 & 0.5 & 1.1 \\
Cyprus & 19.16 & 0.0 & 0.0 & 0.0 & 0.0 \\
Czech & 17.87 & 0.0 & 0.8 & 2.1 & 2.2 \\
Denmark & 26.82 & 0.0 & 0.2 & 0.5 & 0.5 \\
Estonia & 27.36 & 0.0 & 0.0 & 0.8 & 1.9 \\
Finland & 22.29 & 0.0 & 0.0 & 8.8 & 15.9 \\
France & 19.30 & 0.0 & 0.2 & 4.6 & 11.2 \\
Germany & 19.68 & 0.0 & 1.8 & 8.6 & 9.3 \\
Greece & 22.33 & 0.0 & 0.0 & 0.1 & 0.3 \\
Hungary & 19.90 & 0.0 & 0.3 & 1.4 & 1.8 \\
Ireland & 24.67 & 0.0 & 0.0 & 0.2 & 0.6 \\
Italy & 19.33 & 0.0 & 0.7 & 2.1 & 2.3 \\
Latvia & 33.30 & 0.0 & 0.0 & 0.4 & 1.9 \\
Lithuania & 25.10 & 0.0 & 0.2 & 1.1 & 2.2 \\
Netherlands & 14.81 & 0.0 & 0.1 & 0.2 & 0.3 \\
Poland & 20.24 & 0.0 & 0.9 & 4.2 & 6.0 \\
Portugal & 18.93 & 0.0 & 0.2 & 1.2 & 2.0 \\
Romania & 19.35 & 0.0 & 0.2 & 0.9 & 1.7 \\
Slovakia & 22.80 & 0.0 & 0.1 & 0.6 & 1.0 \\
Slovenia & 23.37 & 0.0 & 0.1 & 0.4 & 0.4 \\
Spain & 20.43 & 0.0 & 0.8 & 2.6 & 6.5 \\
Sweden & 21.41 & 0.0 & 0.0 & 8.7 & 15.7 \\
UK & 17.76 & 0.0 & 0.4 & 2.1 & 2.9 \\
\hline & & & & & \\
\hline
\end{tabular}




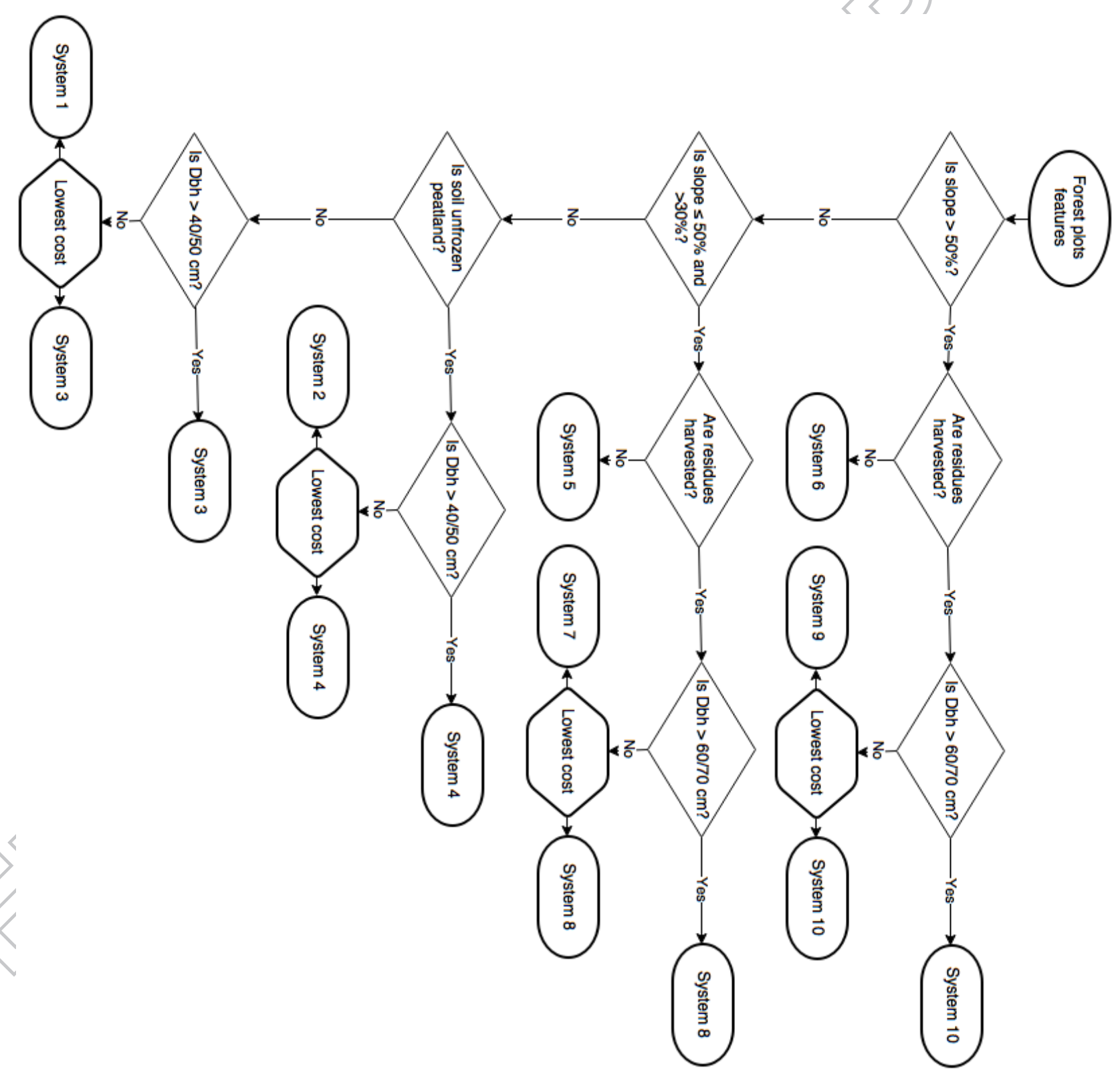



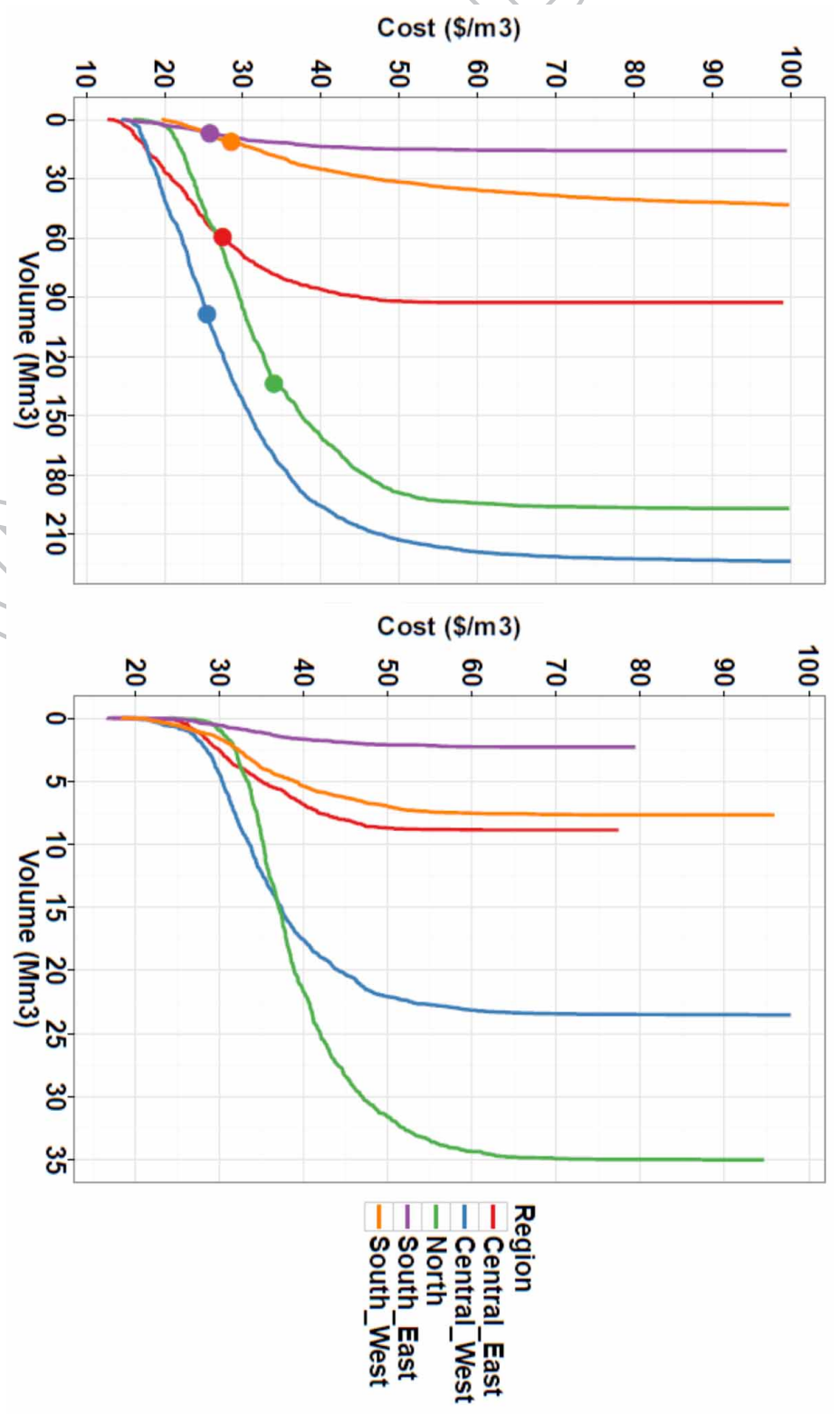

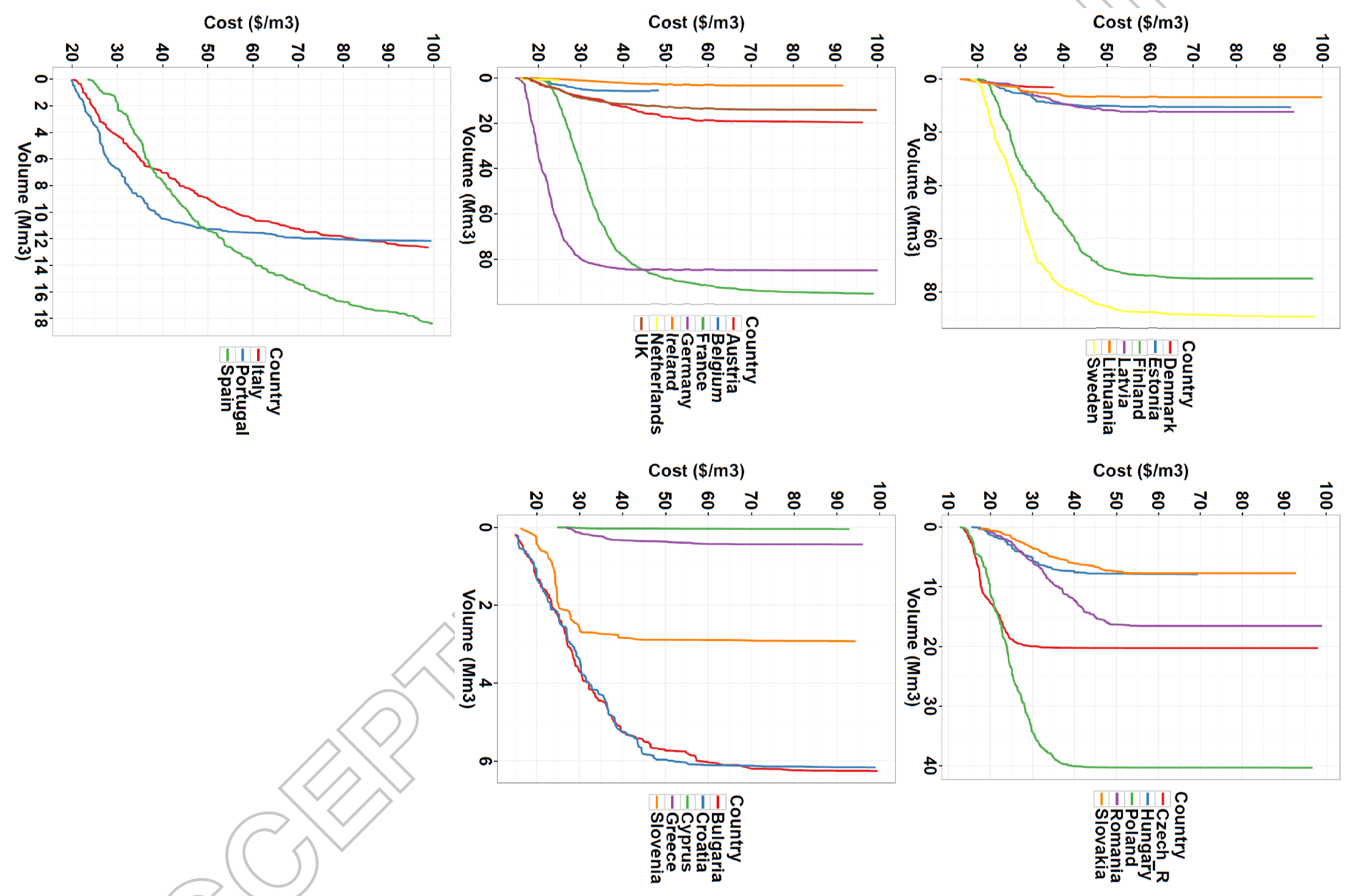

Page 55

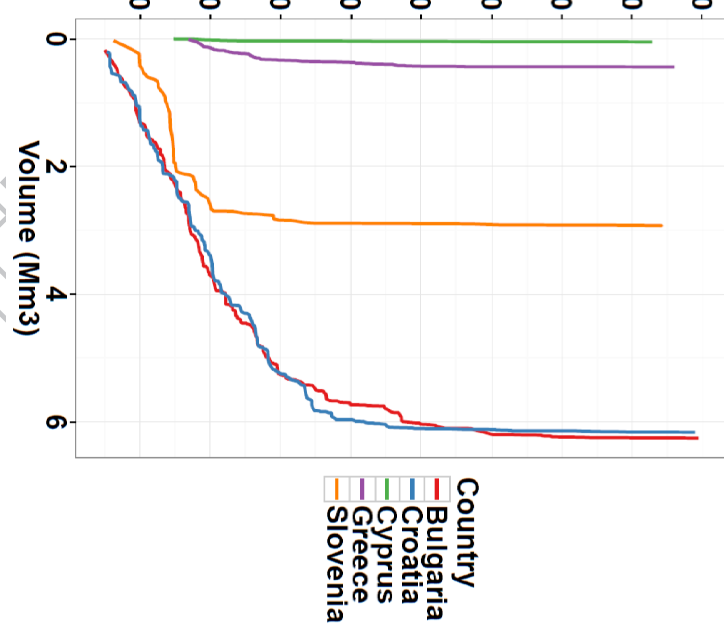



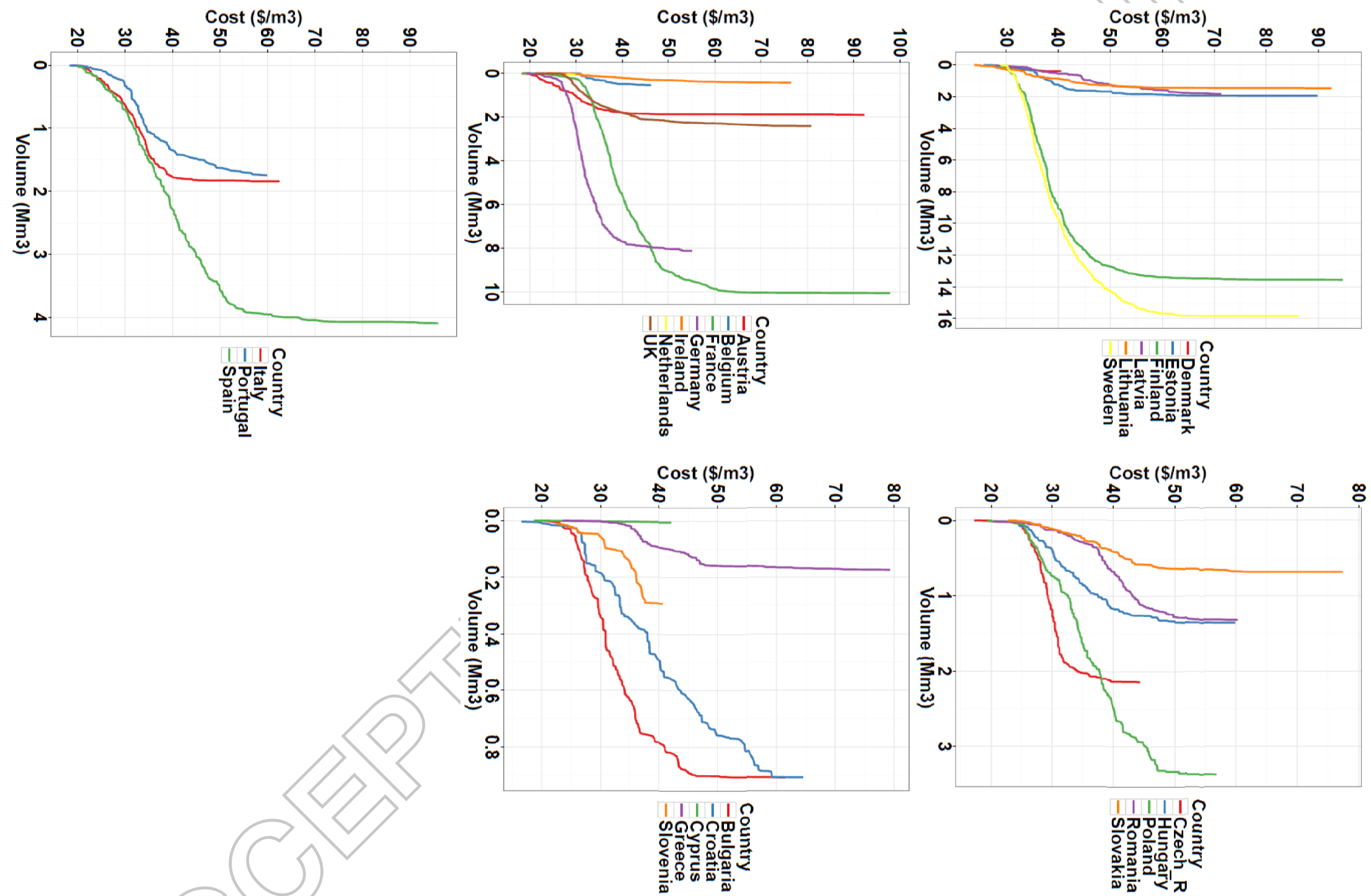

Page 56 

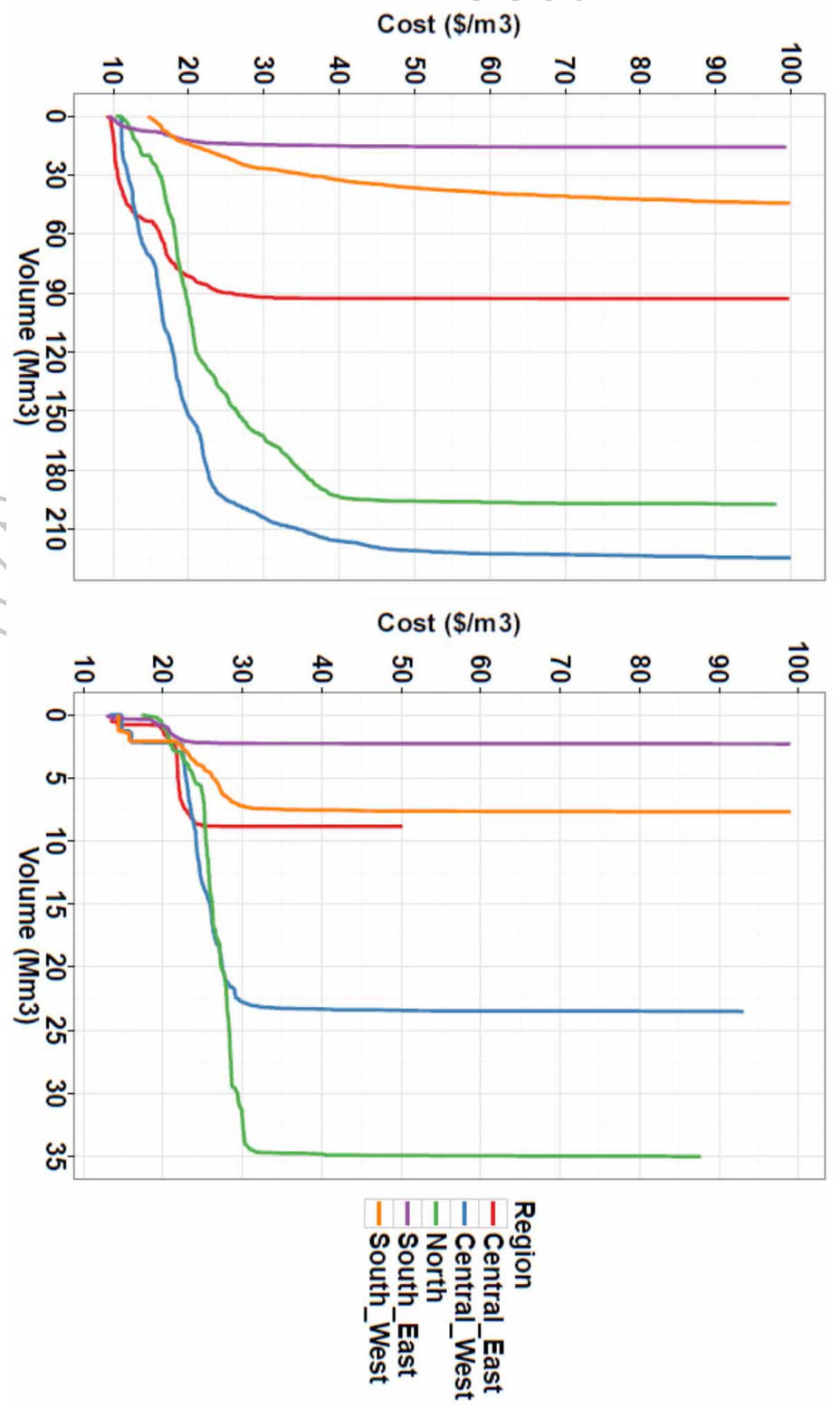

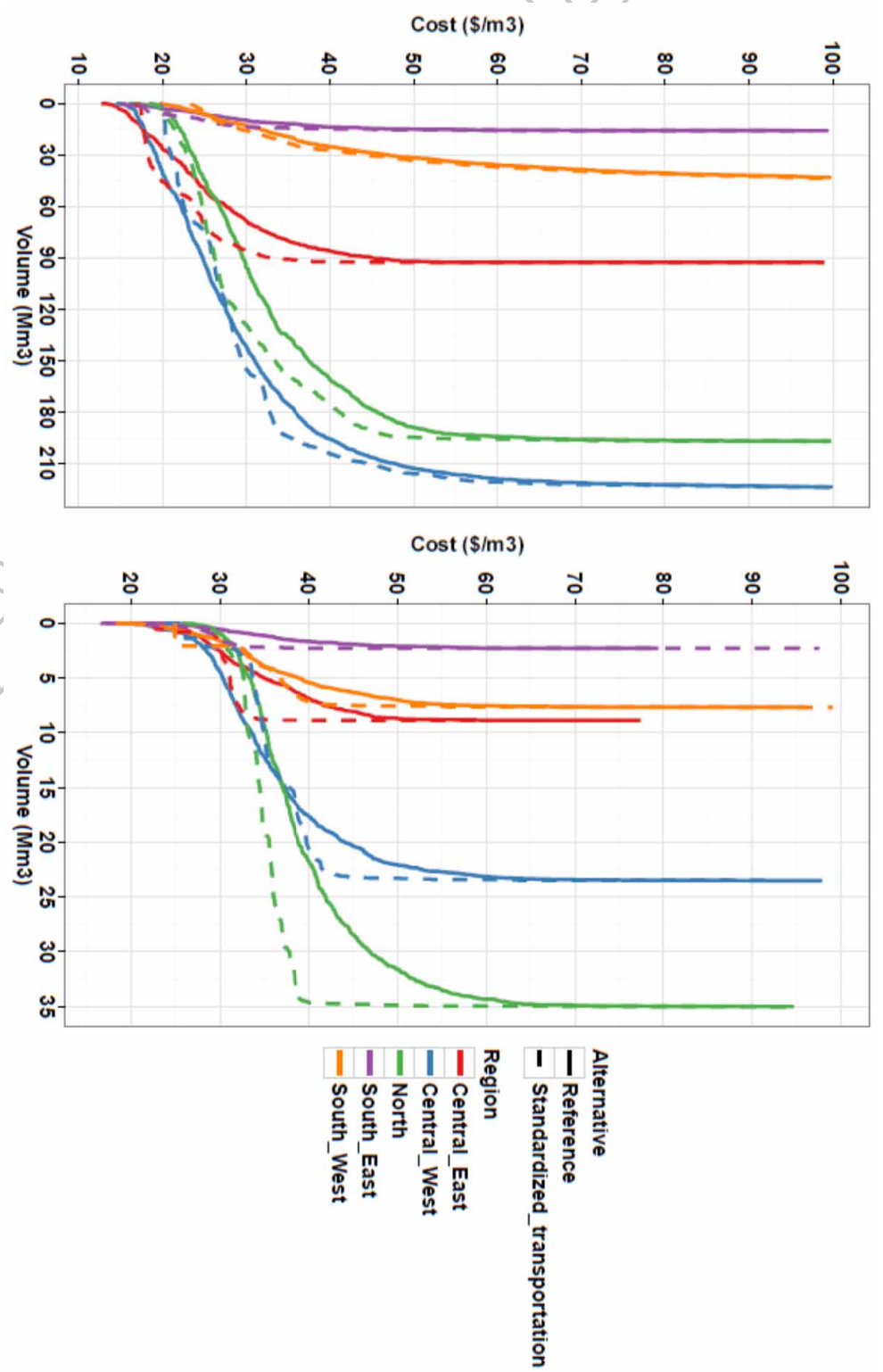


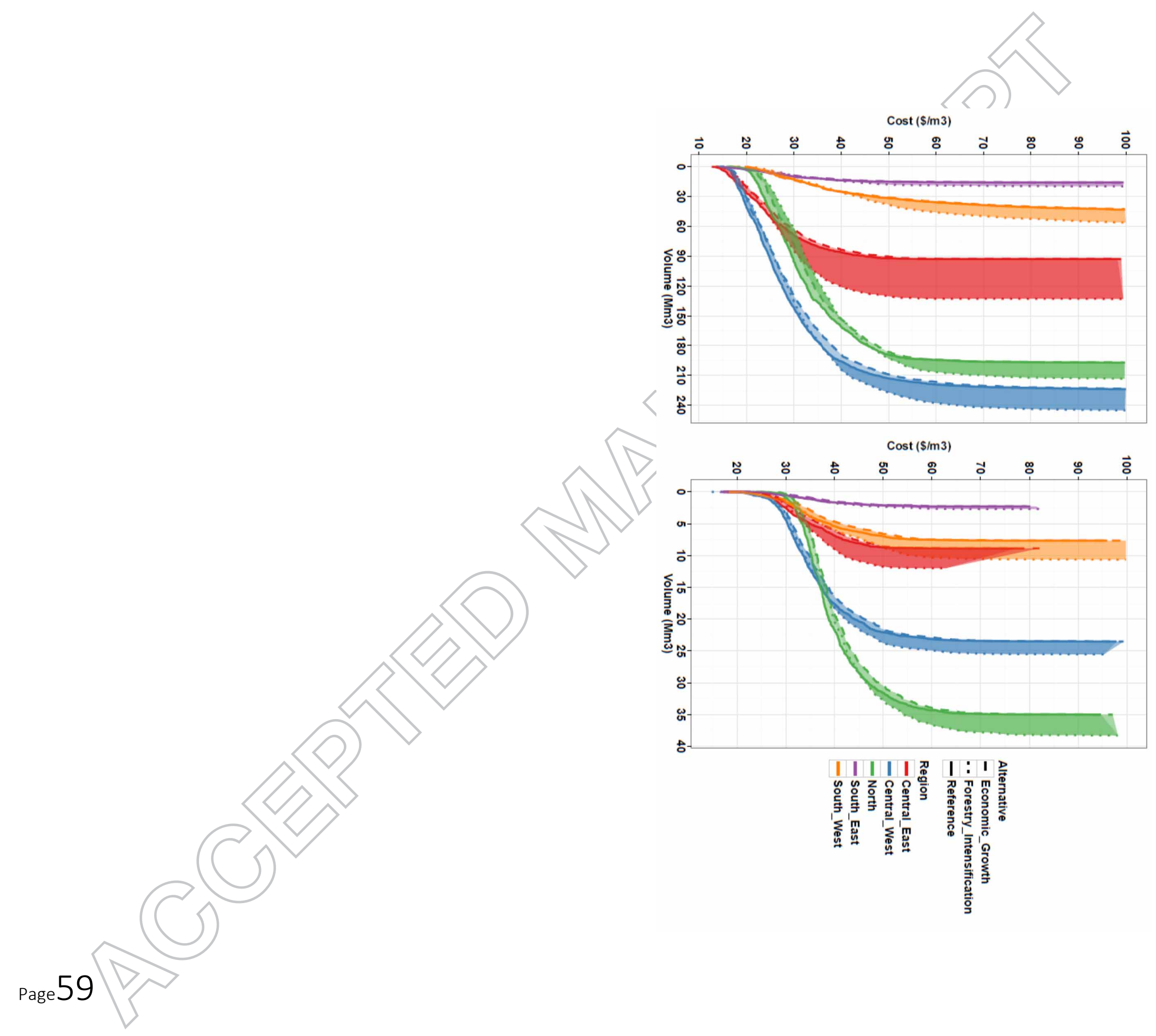

